This PDF is a selection from a published volume from the National Bureau of Economic Research

Volume Title: Globalization in Historical Perspective

Volume Author/Editor: Michael D. Bordo, Alan M. Taylor and Jeffrey G. Williamson, editors

Volume Publisher: University of Chicago Press

Volume ISBN: 0-226-06598-7

Volume URL: http://www.nber.org/books/bord03-1

Conference Date: May 3-6, 2001

Publication Date: January 2003

Title: International Migration and the Integration of Labor Markets

Author: Barry Chiswick, Timothy J.. Hatton

URL: http://www.nber.org/chapters/c9586 


\title{
International Migration and the Integration of Labor Markets
}

\author{
Barry R. Chiswick and Timothy J. Hatton
}

\subsection{Introduction}

Globalization in the labor market is qualitatively different from globalization of goods or asset markets. With international migration, the factor of production (labor services) crosses national boundaries embodied in individuals. As a result, trading in goods and services and capital flows are fundamentally different from trading in labor services (people). In Adam Smith's words, "man is of all sorts of luggage the most difficult to be transported." Nevertheless, international migration does respond strongly to market signals, either legally, when the policy environment allows, or illegally, when there are artificial barriers to mobility. International migration alters the labor supply and the demographic characteristics of both the sending and the receiving countries. Moreover, it influences economic growth, patterns of trade, income distribution, and the distribution of political power within and between countries.

In this paper we shall illustrate that the globalization of world markets has been of prime economic importance in the two key eras: the age of mass migration, which rose to a crescendo between 1850 and 1913, and the era of "constrained" mass migration of the last fifty years. The focus is on intercontinental migrations: from Europe to the New World and from parts of Asia to other areas around the globe in the late nineteenth and early twen-

Barry R. Chiswick is UIC Distinguished Professor and head of the Department of Economics at the University of Illinois at Chicago. Timothy J. Hatton is professor of economics at the University of Essex.

We appreciate the many helpful comments we received on earlier drafts from the organizers and participants in this NBER project. We are particularly grateful to Riccardo Faini and Jeffrey Williamson for constructive suggestions. We are, however, solely responsible for any errors of omission or commission. 
tieth centuries, and primarily from the third world to the first world and the Persian Gulf in the late twentieth century. We begin (in section 2.2) by mapping out the different eras of international migration and labor mobility over the last four centuries. In the following section (section 2.3) we examine the underlying forces that drove mass migration in the two eras of globalization. Perhaps even more important are the effects of migration on sending and receiving countries and the impact of these economic effects on what has been dubbed the "policy backlash" (section 2.4). Although the fundamentals driving international migration were similar in the two periods, the nature, direction, and consequences of the flows reflect changes in the structure and integration of the international economy. The effects of international migration are conditioned both by structural changes in the world economy and by changes in policy regimes. In turn, the policy regimes have evolved in response to changing economic structures, political developments, and migration itself (section 2.5). This paper concludes with an overview of migration flows and policy in the past, and with speculation about the future (section 2.6).

\subsection{International Migration in Different Economic Eras}

\subsubsection{Contracts and Coercion, $1600-1790$}

The discovery of the Americas stimulated a steady stream of migrants (voluntary and involuntary) from Europe and Africa. But these streams were a mere trickle compared to what came later. At first the conditions were harsh and the economic returns were too low in relation to the costs to make mass migration feasible. High transport costs and the risks (both financial and to life itself) and uncertainties involved ensured that only the richest and the most intrepid could bear the cost. Although the migrations of religious groups and other pioneers gradually increased, their numbers were dwarfed by those who came under contract or coercion. By the end of the eighteenth century something like eight million had journeyed to the New World, but largely as slaves from Africa (about 7 million) and convicts from Great Britain, or indentured servants from western Europe, whose migration was financed by others (see Lovejoy 1983, 478, 496). Coercion and contracts were the chief means through which the New World recruited its labor force during this period.

It is estimated that about 700,000 Europeans migrated to North America and the Caribbean between 1650 and 1780, more than half to the mainland colonies. Of these, between one-half and two-thirds came under contracts of indentured servitude (Galenson 1981, 17; Engerman 1986, 271). Around 1650 a passage to America would have cost about $£ 6$, or about five months' wages for an agricultural laborer in southern England (Eltis 1983, 258). Indentured servitude evolved in response to this overwhelming wealth con- 
straint, a high ratio of costs to income, little accumulated wealth, and weak capital markets. Under this system servants were given free passage to the colonies and then, on arrival, sold (at an average price of about £8) to merchants or farmers. ${ }^{1}$ But by the end of the eighteenth century fixed-period contract servitude for Europeans was in decline, partly because of diminishing European supply, but more importantly because of the expansion of another form of recruitment: slavery.

The sharp rise in slave imports from the late seventeenth century, first to the West Indies and then to the mainland colonies of the Chesapeake and South Carolina prevented the implicit wages of indentured servants from rising (i.e., prevented the contract length from falling) and slowed the growth in numbers (Grubb 1992,196). The slave trade continued to grow in the eighteenth century, particularly to the cotton- and tobacco-growing colonies and states on the mainland of North America and to the sugargrowing colonies of the Caribbean.

The abolition of the slave trade to the United States in 1807, the emancipation of slaves in the northern United States, and the emancipation in the British colonies in 1834 ended these forced migrations, although slavery itself lasted longer. The decline in the supply of slave labor led to a revival of contract labor for work on plantations and in mines, this time primarily from China and India, to Southeast Asia, Africa, the Indian Ocean and Pacific Islands, the Caribbean, and North and South America, which lasted in some cases until the start of World War I (Engerman 1986). Although the numbers of these nineteenth-century contract laborers to the New World, as well as coerced convicts to Australia, were insignificant in comparison with the movement of free migrants, contract labor migration remained the dominant form of labor migration from the sending regions in Asia.

\subsubsection{The Rise of Pioneer Free Settlers, 1790-1850}

The intercontinental flow of free settlers, from northwest Europe to the New World, which was slow at first, gathered pace in the early nineteenth century. In the United States the inflows outnumbered slaves by the end of the eighteenth century, but elsewhere the transition came later. For the Americas as a whole it was not until the 1830s that the decadal flow of free migrants exceeded that of African slaves (table 2.1). And according to Eltis $(1983,255)$ it was not until the 1880 s that the cumulative sum of European immigration overtook that of coerced labor from Africa. In Australia, too,

1. The sale price covered the shipping cost, and the comparison of this price with the present value of the servant's expected productivity over and above maintenance determined the length of bound labor - usually between four and seven years - after which the servant was freed. According to one historian of indentured servitude, "Although the institutional arrangements of the indenture system were different from those surrounding the immigration of free Europeans to colonial America, the same is not necessarily true of the servants' motives. Though some of the hardships they faced may have been different, the potential rewards were much the same for servants as for other European immigrants" (Galenson 1981, 113). 
Table 2.1

Free and Coerced Migration, 1790s to 1840s (thousands per annum)

\begin{tabular}{lllllll}
\hline & $1790 \mathrm{~s}$ & $1800 \mathrm{~s}$ & $1810 \mathrm{~s}$ & $1820 \mathrm{~s}$ & $1830 \mathrm{~s}$ & $1840 \mathrm{~s}$ \\
\hline Americas & & & & & & \\
$\quad$ Slaves & - & - & - & 60.25 & 56.34 & 44.51 \\
$\quad \begin{array}{l}\text { Free migrants } \\
\quad \text { \% free }\end{array}$ & - & - & - & 15.38 & 67.07 & 178.53 \\
Australia & & - & - & 20.2 & 54.3 & 80.0 \\
$\quad$ Convicts & 0.49 & 0.43 & 1.70 & 3.23 & 5.00 & 3.37 \\
Free settlers & 0.02 & 0.05 & 0.08 & 1.03 & 5.72 & 14.09 \\
\% free & 3.4 & 10.4 & 4.5 & 24.1 & 53.4 & 80.7 \\
\hline
\end{tabular}

Sources: Americas: Eltis $(1983,256)$; Australia: free immigration from Berlin $(1994,22)$; convicts from Shaw $(1966,363-68)$.

Note: Dashes indicate data are not available.

coerced labor declined as the proportion of free settlers outnumbered the flow of convicts from the 1830s, although the absolute numbers are tiny compared with those in North America.

In North and South America, as well as Australia, free settlers began to arrive in ever larger numbers. Although some fled wars or sought better democratic rights and religious freedom, the vast majority were attracted by growing prosperity and by the prospect of becoming landowners or tenant farmers. These migrants traveled in family groups, often with the intention of starting or joining new communities at the New World's frontier. ${ }^{2}$ These groups were often led by farmers, craftsmen, and artisans, and they originated chiefly in northwest Europe. It is estimated that three-quarters of the English and Welsh, two-thirds of the Dutch, and two-thirds of those from Osnabrück and Baden who migrated to the United States in the 1830s were in family groups and one-third of them were children under fifteen (Erickson 1994, 143).

Migrants to Australia needed even greater incentives, and in order to attract free migrants a policy of assisted emigration was begun in 1834. Some migrants were given free passage, either under the government scheme or under a bounty system that provided incentives for existing settlers to bring new settlers to the Australian colonies. ${ }^{3}$ In South America, too, the longer journey times and more arduous conditions, which prolonged coerced and

2. Erickson (1994, 19-50) found that English migrants preferred Wisconsin, Illinois, Michigan, and Iowa to Massachusetts or Connecticut and that even those from industrial or urban backgrounds were attracted to farming and often bought unimproved land.

3. Under the scale issued in 1837 the bounties were $£ 36$ for a man and wife, $£ 18$ for an unmarried male or female, $£ 10$ for a child aged eight to fourteen, and $£ 5$ for a child aged one to seven (Madgwick 1937, 154). For the adults, certain age limits applied. The individual sponsoring the migrant usually paid travel and settlement costs from the bounty received. Under the government scheme, emigration agents recruited prospective migrants for free passages. It is estimated that about 40 percent of all free migrants between 1848 and 1872 were government assisted. 


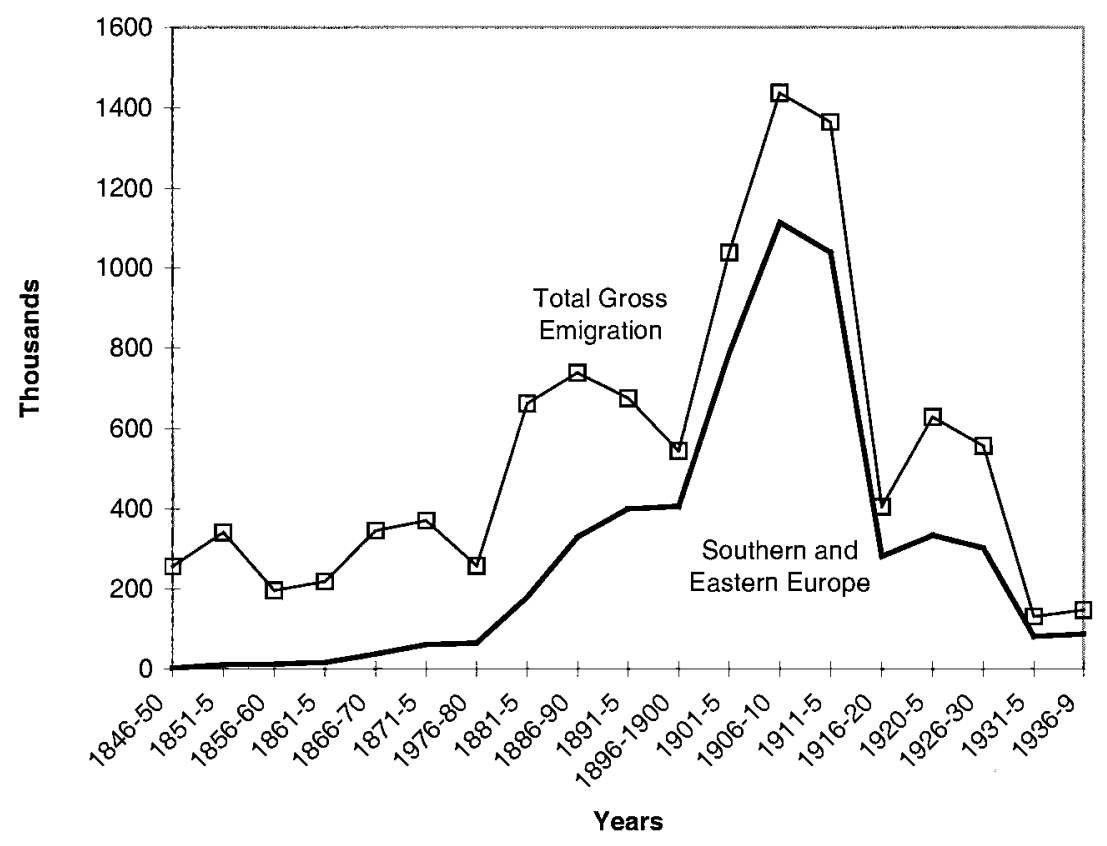

Fig. 2.1 Gross intercontinental emigration from Europe, 1846-1939 (annual averages)

contract labor, delayed the onset of free migration. Incentives in the form of free passages were used to encourage the flow of free settlers.

\subsubsection{The Age of Mass Migration from Europe, 1850-1913}

It was not until after the middle of the nineteenth century that mass migration can really be said to have taken hold. The figures for (gross) intercontinental emigration from Europe are plotted as five-year averages in figure 2.1. In the first three decades after 1846 the numbers averaged around 300,000 per annum, doubling in the following two decades and exceeding one million per annum by the turn of the century. The first wave of the late 1840s was associated with famine and revolution in Europe, and the second wave with the shift in ocean transport from sail to steam. The nominal cost of passage on the North Atlantic route remained roughly constant (Keeling 1999), although it declined relative to average wages. Moreover, the transition from sail to steam cut typical transit times from five weeks in the $1840 \mathrm{~s}$ to twelve days by 1913 and to nine days by the late $1960 \mathrm{~s}^{4}$

4. The data for contract prices for government-assisted passages to Australia also suggest little downward trend in nominal prices between the late 1840s and the early 1880s. But voyage times fell by 10 percent, and mortality fell by 80 percent (McDonald and Shlomowitz 1990, 1991). 
In the first half of the nineteenth century the dominant source of migrants was the British Isles. These were joined from the 1840s by a stream of emigrants from Germany, followed, after 1870, by a rising tide from Scandinavia and elsewhere in northwestern Europe. Emigration surged from southern and eastern Europe from the 1880s. It came first from Italy and parts of the Austro-Hungarian empire, and then from Poland, Russia, Spain, and Portugal. As figure 2.1 shows, these migrants from southern and eastern Europe, the so-called "new immigrants," account for most of the surge in numbers from the 1880s. About 60 percent of all European emigrants went to the United States. However, from the 1870s significant flows developed-largely from Italy, Spain, and Portugal - to South America, principally Brazil and Argentina, that is, from Romance language origins to Romance language destinations. ${ }^{5}$

The characteristics of the emigrants also changed. It was no longer a "family" migration. The mass migrants were typically young and single, and about two-thirds of them were male. More than three-quarters of the immigrants entering the United States between 1868 and 1913 were aged sixteen to forty at a time when 42 percent of the U.S. population was in this age group. Among men emigrating from England and Wales, only one in nine traveled with other family members, compared with more than half in the 1830s (Erickson 1994, 143). ${ }^{6}$ The migrants from any one country were increasingly urban but remained largely unskilled. Nevertheless, European migrants as a whole remained largely rural in origin as the sources shifted toward the less developed southern and eastern Europe.

These outflows generated flows of return migrants, small at first (perhaps 10 percent of the outflow), but rising by the turn of the century to about 30 percent of the outflow. The extent of the return migration varied sharply by country of origin, motive for migrating, whether it was family based, and economic conditions in the destination and origin. The return migration rates were very high for some groups, for example, Italian and Greek immigrants, and very low for other groups, such as eastern European and Russian Jews, who viewed themselves as refugees and, more than other groups, migrated in a family context. In the absence of a social safety net in the destinations, the return flows were greater when the destinations were experiencing a recession. The return migrants, those returning often after only a few years, were a sign of the growing globalization of labor, in part due to

5. The surge of immigrants to Brazil from the 1880s owes much to the combination of the abolition of slavery and the introduction of free passages (Leff 1982, 60). As was often the case elsewhere, subsidies to immigration were financed by export taxes, in the Brazilian case export taxes on coffee. This intensified the linkage between immigration and international trade.

6 . The change in the demographic characteristics of the migrants may well have reflected the change in where they were to settle in the destination. With urbanization and the rise of industrial job opportunities, urban areas replaced farming areas as the primary destination. Although accompanying wives and children may have been an asset for an immigrant intending to become a farmer, they may have been perceived as a liability among those anticipating urban industrial work. 
the steamship's lowering the cost - measured in money, time, and dangerof oceanic travel. The return migrants often brought back to their home countries skills, information, and capital acquired in the New World.

Although the discussion of the nineteenth century and pre-World War I intercontinental migration has focused on the emigration of Europeans to the New World, large-scale migrations were taking place in other parts of the world. There were substantial movements within Europe itself, including the Irish moving to Great Britain and eastern Europeans moving to western Europe, sometimes merely sojourning before embarking for the New World and sometimes remaining permanently. There was migration to southern Africa from Europe (first by the Dutch, then by the British), South Asia, and East Africa. Asians, particularly from India, China, and Japan, were also on the move, most often as contract laborers, to East Africa, Southeast Asia, the Pacific Islands, the Caribbean region, and the West Coast of North America.

\subsubsection{Asian Emigration, Nineteenth and Early Twentieth Centuries}

The increased globalization of the political system through the spread of European colonization in the nineteenth century to Asia, Africa, and the Pacific and Indian Ocean islands resulted in increased intercontinental trade, with sugar, rubber, jute, tin, and other primary products being produced in the colonies, much of it for export to Europe and North America. The establishment of colonial plantation agriculture and mining, and the development of transportation and communication, increased the demand for low-cost pliant labor. In the absence of slavery, colonial governments and business enterprises sought fresh sources and instruments to attract the labor for these activities. The new source became Asia, and in particular India, China, and Japan. The new instrument was a return to an earlier means of financing migration - indentured servitude or contract labor.

Asia offered a large supply of low-cost unskilled labor, but even with the cost of international migration lower in the nineteenth century than in earlier centuries, Asian laborers were too poor to finance the move. Indentured servitude or contract labor was introduced both to finance the migration and to provide the information networks to match workers to jobs. The contracts (for Indian workers) were typically of five years' duration. At the expiration of the contract some of the workers had accumulated the resources to return home. The poverty that drove them to become indentured servants remained, however, and for India, so too did the repressive caste system. Most indentured servants (perhaps three-quarters in many times and places) remained where they were, acquiring some land, working part time in the plantations for wages, or migrating to urban areas. As a result, Asian communities began developing in East Africa and southern Africa, North America, Latin America, and Oceania, and nonindigenous Asian communities developed in Southeast Asia.

One of the largest of these intercontinental indentured servant migra- 
tions was from India. Thiara (1995) reports that in the eighty years of the formal indentured servant system (1830 to 1916) over one million Indians were transported overseas to further the British goal of empire building and, indirectly, the globalization of the economy. Over one-half million Indian indentured servants went to Mauritius, and another half million went to the Caribbean (primarily the south Caribbean, Trinidad, British Guiana, and Surinam), with smaller numbers going to Fiji in the Pacific Ocean, Natal in southern Africa, and East Africa (Thiara 1995; Vertovec 1995). Another group of Indian international migrants were the Sikhs who were recruited into the British India Army after the 1857 Punjab Mutiny (Tatla 1995). Sikhs were considered by the British to be a "martial race," and many served in the British Army in Sikh units and were posted in various parts of the Empire, often remaining when their tour of duty ended. Others served in British police and military units in various parts of the British Empire.

China was another major source of Asian labor, with indentured servitude contracts being most prevalent from the 1840s to the 1920s. In addition to the poverty and demographic pressures prevalent in India, China experienced far more political turmoil. The indentured servant system was less formalized in China than in India, and in addition to the indentured servant contract for a fixed period, a "credit-ticket system" was used in which the loan of the ticket money was to be repaid. Although the Chinese government's official position was to oppose emigration, its political weakness prevented it from enforcing its will (Hui 1995). The Chinese indentured servants were to be found in many sectors, including Malay tin mines, Cuban sugar plantations, and railroad construction in the United States. When the contracts ended, some returned to China, while others remained, forming the nucleus of the emerging Chinese communities (Chinatowns) in Southeast Asia, the Caribbean, and North and South America.

Japan, too, was a source of emigrant labor, with somewhat fewer than one million emigrants from the mid-nineteenth century to the early 1930s (Shimpo 1995). Labor-recruiting agents and the labor contract system were used. The Japanese workers went to Hawaii and the mainland United States, as well as to South America, primarily Peru and Brazil, as indentured servants or as recruited free immigrants.

Competition between Asian laborers and white workers, particularly in California, led to the first restrictions on immigration to the United States based on country of origin. The Chinese Exclusion Act of 1882, and its subsequent amendments, barred Chinese laborers from entering the United States. With the annexation of Hawaii by the United States in 1898 and with the 1908 "gentleman's agreement" between the governments of Japan and the United States, the emigration of Japanese workers to the United States ended. Legislation in 1917 created the "Asiatic Barred Zone," which effectively prohibited the migration to the United States of persons from Asia 
(including the non-Asian-born descendants of Asians), with the exception of the Asian Middle East.

In other regions the demand for indentured servants declined as changes in technology reduced the demand for unskilled labor in plantation agriculture and as small-scale farms owned by freed indentured workers and their descendants produced the crops. The disruption of the world economy in the two world wars and the Great Depression further disrupted international migration from less developed to other less developed regions. Post-World War II movements for independence among the colonies in Asia, Africa, and Oceania reduced the political acceptability of low-skilled foreign workers with ethnicities different from those of the indigenous populations.

The colonial-inspired Asian migration to various corners of the globe had long-term economic and political consequences. The presence of Asians provided a substitute for, or competitors for, indigenous labor. Tensions between the Asian indentured servants and their descendants on the one hand, and the indigenous populations on the other hand, persisted throughout the migration period but were held in check by the colonial powers. With the transition to independence after WWII came violent conflicts among ethnic groups. Conflicts between Indian-origin and African peoples in East Africa, between the Indian-origin and native Fijians, and between the Chinese and native Malays and Indonesians, among other conflicts, have harmed their economic development and ended this form of mass migration. Thus, a consequence of the post-WWII independence movements that resulted in the demise of European overseas empires, in particular the British Empire, was the decline in international migration and the globalization of labor markets within the third world.

\subsubsection{War, Depression, and Restriction, 1914-45}

Mass migration fell sharply as war and depression halted the globalization trend and immigration policies entered a new age of restriction. In the United States, the quotas enacted in 1921 and 1924 favored the countries of northwestern Europe and bit deepest into emigration from southern and eastern Europe (fig. 2.1). ${ }^{7}$ Although the quotas were binding in the $1920 \mathrm{~s}$ on new immigrant nationalities, a number of old immigrant nationalities fell below the quotas. In the Depression of the 1930s, with few exceptions, even new immigrant nationalities fell below quota (Gemery 1994, 180). ${ }^{8}$ Emigration restrictions, introduced by some countries, such as the Soviet Union, also limited opportunities for international migration.

7. Although immigrants from the new source countries were four-fifths of U.S. immigrants in 1910-14, they were allocated only one-fifth of the quota enacted in 1924 (and implemented in 1929) (Kirk 1946, 84).

8. This was not always due to a lack of interest in migrating to the United States. Administrative rules were used by the U.S. authorities in the 1930 s to restrict the immigration of German Jews. 
Immigration to other destination countries fell less sharply as compared with the pre-World War I period. The share of the United States in intercontinental emigration from Europe was 51 percent in 1921-25, and 32 percent (of a much smaller total) in 1931-35, in part because of the U.S. limits on immigration. Some southern European migrants were diverted to Brazil and Argentina, the latter receiving 3 million in the 1920s, although as many as 2 million returned. But emigration from everywhere in Europe fell in the 1920s, with the exception of Poland and other eastern European countries. And apart from Jewish emigration from Germany, the economic maelstrom of the 1930s completed the process of deglobalization of the international labor market. Indeed, in some years during the Depression of the 1930s the return migration to Europe exceeded immigration, resulting in a negative net migration rate to the United States.

\subsubsection{Constrained Mass Migration, 1946-2000}

The post-WWII period has seen a dramatic decline in the costs of travel as a result of the shift from sea to air travel. It also has seen a decline in the cost of information and communication that has also lowered the cost of international migration. After the population dislocations following the Second World War, intercontinental migration resumed, initially on a pattern similar to before the First World War. The breaking of family ties that often characterized pre-WWI immigration has become less relevant in the postWWII period. Yet the flow of migrants has been partially controlled by immigration policies introduced in the major receiving countries earlier in the century. Immigration policies changed sharply in the 1960s in the United States, Canada, and Oceania, with a shift away from quotas that favored immigrants from northwest Europe.

As figure 2.2 shows, total immigration to North America and Oceania rose gradually to one million per annum in the 1990s. Although the absolute numbers are similar to those in the age of mass migration about a century earlier, relative to destination country populations they are much smaller. Thus the annual immigration rate to the United States fell from $11.6 \mathrm{immi-}$ grants per thousand population in the first decade of the twentieth century to 0.4 immigrants per thousand population in the $1940 \mathrm{~s}$, rising again to 4.0 immigrants per thousand population in the 1990s. The proportion of foreign-born in the population was 15 percent in 1910, falling to a low of 4.7 percent in 1970, then, with the growing postwar immigration, increasing to 8 percent in 1990 and 10 percent in $2000 .{ }^{9}$ Although the immigration rate is lower than at its peak in the first decade of the twentieth century, its contribution to population and labor force growth is similar because the rate of natural increase has also declined.

9. The proportion of the foreign-born in the population is influenced not only by immigration inflows but also by "exits," whether through remigration or through death. 


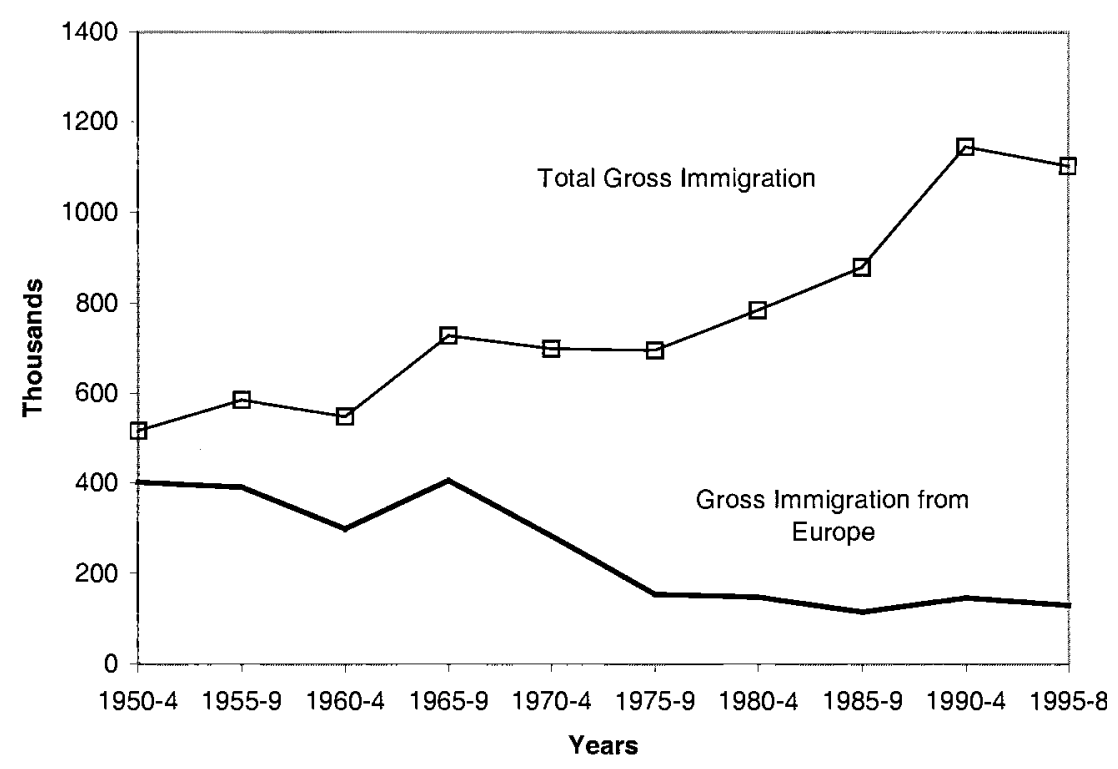

Fig. 2.2 Gross immigration to the United States, Canada, Australia, and New Zealand: 1950-54 to 1995-98 (annual averages)

There were three key structural changes in the pattern of intercontinental migration. The first was the decline in Europe as a source of emigrants and the rise of Asia as a source of emigrants. As figure 2.2 shows, European emigration to North America and Oceania declined from the 400,000 in the early 1950 s to less than 100,000 per annum in the early 1990s. In part this reflects a resurgence of migration within Europe. Thus, for example, the share of emigrants from Portugal moving within Europe rose from 1.5 percent in 1950-54 to 57.1 percent in 1970-74 (United Nations [UN] 1979). Migration within Europe (including Turkey) grew rapidly in the early postwar years through "guest-worker" systems, particularly in Germany, where, by 1973 one in nine workers was foreign born. For Western Europe as a whole, foreign nationals increased from 1.3 percent of the population in 1950 to 4.5 percent in 1990. Including the foreign-born who had become naturalized would double this figure (Stalker 1994, 189-90).

In more recent decades Western and southern Europe has become a destination for immigrants from Asia, the Middle East, and Africa, and since the demise of the Soviet Union in the 1990s Western Europe has experienced migration from Eastern Europe and the former Soviet Union. As a result, net immigration to the European Union (EU) rose from 200,000 per annum in the 1980s to over a million in 1989-93, falling again to 640,000 per annum in 1994-98. Thus, in terms of inflows, the EU has now surpassed the United States, and by more if illegal immigration is included. 
Table 2.2 Region of Origin of Immigrants, by Decade of Immigration, 1921-98 (\%)

\begin{tabular}{lccccccc}
\hline $\begin{array}{l}\text { Decade of } \\
\text { Immigration }\end{array}$ & $\begin{array}{c}\text { Europe or } \\
\text { Canada }^{\mathrm{a}}\end{array}$ & Mexico & $\begin{array}{c}\text { Other Latin } \\
\text { America }\end{array}$ & Asia & Africa & Total & $\begin{array}{c}\text { Number } \\
\text { (thousands) }\end{array}$ \\
\hline $1991-98^{\mathrm{b}}$ & 17.6 & 25.5 & 22.3 & 31.0 & 3.7 & 100.0 & 7,582 \\
$1981-90^{\mathrm{c}}$ & 13.1 & 22.6 & 24.6 & 37.3 & 2.4 & 100.0 & 7,338 \\
$1971-80$ & 22.5 & 14.3 & 26.1 & 35.3 & 1.8 & 100.0 & 4,493 \\
$1961-70$ & 47.0 & 13.7 & 25.6 & 12.9 & 0.9 & 100.0 & 3,322 \\
$1951-60$ & 68.7 & 11.9 & 12.7 & 6.1 & 0.6 & 100.0 & 2,515 \\
$1941-50$ & 78.0 & 5.9 & 11.8 & 3.6 & 0.7 & 100.0 & 1,035 \\
$1931-40$ & 86.8 & 4.2 & 5.5 & 3.1 & 0.3 & 100.0 & 528 \\
$1921-30$ & 82.7 & 11.2 & 3.2 & 2.7 & 0.2 & 100.0 & 4,107 \\
\hline
\end{tabular}

Source: Statistical Yearbook of the Immigration and Naturalization Service, 1998, tables 2 and 4.

Note: Detail may not add to total due to rounding.

${ }^{a}$ Includes Australia, New Zealand, and Oceania.

${ }^{b}$ Eight years. Includes over 1.3 million former illegal aliens receiving permanent resident alien status in 1991 and over 200,000 in 1992-97 under the Immigration Reform and Control Act of 1986.

'Includes nearly 1.4 million former illegal aliens receiving permanent resident alien status in 1989 and 1990 under the Immigration Reform and Control Act of 1986.

The second key structural change was the transformation of Latin America from a destination to a source region, the mirror image of Europe's (and Japan's) transformation from a source to a destination. Between 1960 and 1980 the stock of immigrants in Latin America and the Caribbean who were born outside the region fell from 3.7 million to 3.0 million, while Latin Americans and Caribbeans residing outside the region increased from 1.9 million to 4.8 million. The changing sources of immigrants to the United States are particularly instructive (table 2.2). Whereas more than four out of five immigrants even as late as the early post-WWII years came from Europe and Canada, in recent years less than one in five come from there. About half now come from Latin America, nearly equally split between Mexico and the rest of Latin America and the Caribbean.

The third key structural change for the countries of overseas settlement during the postwar period was the increase in immigration from Asia, from negligible numbers to a large flow, and the beginnings of immigration from Africa (table 2.2). The Asian migrants come from India, Pakistan, China, Korea, the Philippines, and Vietnam, among other places. The pattern of Asian immigration was also observed in Europe, with the addition of African and Middle Eastern immigrants. Among five main European destination countries, immigration from developing countries rose from 97,000 in $1975-79$ to 225,000 in $1990-93 .{ }^{10}$ For Germany alone, between $1975-79$ and 1990-93 immigration from northern Africa and western Asia rose from

10. United Nations 1998, 32-33. The five countries are Belgium, Germany, the Netherlands, Sweden, and the United Kingdom. 
20,000 to 67,000 per annum, while that from sub-Saharan Africa rose from a mere 1,200 to 22,000 per annum.

\subsubsection{Contract Workers in the Persian Gulf, Post-1970}

In the post-WWII period a major current of international migration emerged around the Persian Gulf. The development of oil production and exports in the countries bordering the Persian Gulf, particularly the thinly populated Arab countries such as Saudi Arabia, Kuwait, Bahrain, and the United Arab Emirates, led to a large increase in the demand for foreign workers in the construction, trade, and low-skilled service industries, as well as for more highly educated foreign workers, such as teachers, engineers, and doctors. Initially this demand for imported labor was satisfied by temporary contract workers from nearby parts of the Arab world-Egyptians, Palestinians, and Yemenis, among others.

After the formation of the Organization of Petroleum Exporting Countries (OPEC), the redistribution of price-setting powers for crude oil from the Western-owned oil companies to the exporting countries, the continuing increase in world demand for oil, and the 1973-74 oil embargo, crude oil prices reached unprecedented heights. The revenues from exported oil from the Arab states that were members of OPEC increased from less than \$200 billion in 1971-75 to over \$600 billion in 1976-80 (Abella 1995, 418).

The result was an extraordinary increase in the demand for foreign workers. Although workers from other Arab states continued to move to the Persian Gulf as contract workers, they were soon far outnumbered by millions of temporary workers from nearly all parts of Asia — south, southeast, and east Asia - with the sources moving eastward over time. ${ }^{11}$ The annual flow of Asian workers to the Middle East increased from less than 100,000 in 1975 to nearly one million in 1991. The share from Pakistan and India decreased from 97 percent in 1974 to 36 percent in 1991, and the share from Southeast and east Asia and from Bangladesh and Sri Lanka increased to 42 percent and 22 percent, respectively, in 1991. By 1990 the stock of Asian workers had grown to about 400,000 in Kuwait, to nearly one-half million in the United Arab Emirates, to over 1.5 million in Saudi Arabia, and to over 3.5 million in the entire Gulf region (Abella 1995).

The Asian workers came under short-term contracts (generally only one to two years). Private agencies were established in the sending countries, but some governments (e.g., South Korea and the Philippines) were actively promoting contracts for their construction companies and workers. The sources also shifted. Contract workers from South Korea reached a peak in 1982 of nearly 200,000 and then declined sharply, whereas those from the Indian subcontinent and Indonesia followed a rising trend (UN 2000, 62, 110).

11. For studies of the impact of this labor migration on the sending countries in Asia, see Amjad (1989). 
The initial shift from Arab to Asian labor arose in part because of their lower labor costs, but also because the receiving countries wanted foreign workers that would not settle permanently and who would be less of a demographic, cultural, and political threat to the indigenous population than other Arabs, who were more difficult to segregate while in the country and to repatriate. The "eastward" movement in Asia of the sources of migrant workers was an attempt to diversify their origins to prevent any one group from dominating. For the sending countries, of course, the arrangement provided benefits in the form of higher-wage jobs for many of their nationals, contracts for their construction firms, and substantial foreign exchange in the form of remittances and repatriated wages and profits (Amjad 1989).

As a result of the Iraqi invasion of Kuwait in 1990 and the resulting Persian Gulf War (1991), many Arab workers (particularly Palestinians and Yemenis whose leaders sided with Iraq) left or were expelled from the Arab Persian Gulf states. Primarily for political reasons, the reliance on Asian as distinct from Arab workers has since increased even further.

\subsection{What Drives Mass Migrations?}

\subsubsection{Explaining Migration Streams}

Mass migrations are driven by economic incentives, and numerous studies testify to that fact. The era of mass migration before the First World War, when international migration was relatively unfettered by restrictions, is a good time to examine the forces that determined patterns of migration. The bias toward certain emigrant characteristics reflects the economic calculus underlying their migration (Chiswick 2000). Although the young and single might be more adventurous and enterprising, and had fewer ties (investments) specific to their origin and hence a lower cost of migration, they also had the most to gain from the move. By emigrating as young adults, they were able to reap the gains over most of their working lives while minimizing the costs of earnings forgone during passage, job search, and adjustment in the destination. By moving as single adults they were also able to minimize the direct costs of the move. Unskilled emigrants also had little technology- or country-specific human capital invested and hence stood to lose few of the economic returns from such acquired skills. The transoceanic migrations from Europe also sought to minimize the loss of language capital, with migrants to South America more likely to come from Romance language countries, whereas those from the British Isles favored North America.

What accounts for fluctuations in migration streams? Since the pioneering study of Jerome (1926), there have been many studies aimed at identifying the economic forces determining the uneven flow of migrants from Old World origins to New World destinations. The older literature was preoc- 
cupied with measuring the influence of "push" forces in the origin countries versus "pull" forces in the destination, and with the relative significance of variables representing job opportunities (as measured by indexes of production or employment) versus real wage rates. ${ }^{12}$ More recent studies have used an economic decision-making framework in which potential emigrants compare expected future streams of income at home and abroad. Following Todaro (1969), expected income depends on the wage rate and the probability that the migrant will find a job. Because migrants are risk averse and because greater uncertainty attaches to the probability of employment (especially in the destination) than to the wage rate, and because of greater cyclical fluctuation in employment among new immigrants than among natives, employment outcomes take a greater weight in the timing of migration decision. ${ }^{13}$

Strong empirical support for this approach has been obtained for annual time series emigration rates for a number of European countries in the late nineteenth century (Hatton and Williamson 1998, ch. 4). The results indicate that wage rates and employment rates, both at home and in the destination, all help explain the year-to-year variations in emigration rates. Employment rates had a powerful effect, particularly those in the destination. The fact that short-run emigration rates are so volatile, and correspond so closely to booms and slumps, may seem surprising at first sight. Given that migration decisions are based on comparing future expected lifetime earnings, one might expect that short-run changes, quickly reversed, would have little effect on this long-run comparison. The volatility can be explained by the option value of waiting. Although the net present value of migration today may be positive, it might be higher next year if conditions in the destination are expected to improve. ${ }^{14}$ Moreover, when migrants are constrained by limited wealth, the resources to finance the migration and adjustment may be very sensitive to short-run factors. Hence, even where the decision to become a migrant is based on long-run country differences in employment and wages, the timing of the actual move is closely correlated with cyclical fluctuations in source and destination countries.

Whereas unemployment rates were a powerful short-run determinant of emigration, the long-run trends are determined more by changes in the

12. The literature up to the 1970 s was critically reviewed by Gould (1979), who pointed to the lack of consistency in the results of different studies.

13. This model is derived in Hatton (1995). A case can also be made for stronger real wage effects in the destination than the origin. A dollar increase in the wage in the destination has income and substitution effects that encourage migration, whereas a dollar decrease in the wage in the origin has a substitution effect that favors migration but an income effect that discourages it.

14. The option value of waiting is also incorporated in the equation dynamics (Hatton 1995). Simulations that abstract from cyclical effects and equation dynamics reduce the coefficient of variation of predicted emigration rates for Sweden, Norway, and Denmark by between onehalf and two-thirds (Hatton and Williamson 1998, 73). 
wage ratio. For emigration from the United Kingdom, a permanent increase of 10 percent in the ratio of foreign to home real wages would increase the gross emigration rate by 1.9 per thousand in the long run and the net emigration rate by 1.4 per thousand. The overseas real wage was 69 percent higher than the home wage on average over the period, and the present value of the wage gains far exceeded the costs of passage. ${ }^{15}$ In part this reflects the costs of location-specific human capital including job-related skills and labor market information. It also reflects the compensating differential needed to offset the psychic cost of separation from family, friends, and community.

Consistent with this, the other most important variable explaining emigration rates is the stock of previous emigrants living in the destination. The migrant stock captures the chain migration effect where friends and relatives who have previously migrated generate new migration by lowering the costs and uncertainty of migration. ${ }^{16}$ This proves to be a very powerful effect, and it explains much of the long-run persistence in emigration streams. In Italy, for example, cumulative previous emigration helps to explain why emigrants from the north continued to migrate to South America despite a substantial wage differential favoring North America. Thus the shift in the composition of Italian migration to North America occurred only gradually between the 1870s and 1913 (Hatton and Williamson 1998, ch. 6).

\subsubsection{Long-Run Trends in Migration, 1850-1913}

What explains why some countries produced few emigrants and some produced many? And why did emigration rise for some countries and decline for others? Table 2.3 illustrates the wide range of experience for European countries for decade average gross emigration rates in the age of mass migration. The highest rates were for Ireland, averaging twelve per thousand between 1850 and 1913. Norway and Sweden had rates approaching five per thousand from 1870 to 1913 , whereas those from Germany and Belgium were under two per thousand, and that for France was close to zero. These emigration rates also display different trends. Emigration from

15. This is a weighted average of real unskilled wage rates in the United States, Canada, and Australia relative to the real unskilled wage rate in the United Kingdom. The estimates imply that, holding other variables constant, a wage gap of 27 percent would just eliminate net emigration.

16. Consider a destination country $\mathrm{D}$ that has no immigrants from the origin country $\mathrm{Y}$. The first immigrant from $\mathrm{Y}$ to $\mathrm{D}$ may be indifferent among a set of equally attractive destinations within country $\mathrm{D}$. If one destination is chosen, say at random, that destination becomes more attractive than others in D for future arrivals from country $\mathrm{Y}$. The original settler's presence provides lower-cost information and ethnic-specific goods and reduces information uncertainty. Future migrants from $\mathrm{Y}$ to $\mathrm{D}$ are no longer indifferent among the alternative destinations in $\mathrm{D}$. The formation of immigrant enclaves is a nearly universal characteristic of mass immigration flows and is not necessarily a sign of "clannishness" but rather a response to economic incentives and opportunities (Chiswick and Miller 2001). 


\section{Table 2.3}

Gross Emigration Rates from European Countries, 1850-1913

(emigrants per 1,000 population per annum, decade averages)

\begin{tabular}{lcccccc}
\hline & $1850-59$ & $1860-69$ & $1870-79$ & $1880-89$ & $1890-99$ & $1900-13$ \\
\hline Belgium & 1.90 & 2.22 & 2.03 & 2.18 & 1.96 & 2.32 \\
Denmark & - & - & 1.97 & 3.74 & 2.60 & 2.80 \\
France & - & 0.12 & 0.16 & 0.29 & 0.18 & 0.15 \\
Germany & 1.80 & 1.61 & 1.35 & 2.91 & 1.18 & 0.43 \\
Great Britain & 4.83 & 2.47 & 3.87 & 5.71 & 3.92 & 7.08 \\
Ireland & 18.99 & 15.16 & 11.28 & 16.04 & 9.70 & 7.93 \\
Italy & - & - & 4.29 & 6.09 & 8.65 & 17.97 \\
The Netherlands & 0.50 & 1.67 & 2.66 & 4.06 & 4.62 & 5.36 \\
Norway & - & - & 4.33 & 10.16 & 4.56 & 7.15 \\
Portugal & - & - & 2.91 & 3.79 & 5.04 & 5.67 \\
Spain & - & - & - & 3.91 & 4.63 & 6.70 \\
Sweden & 0.51 & 2.52 & 2.96 & 8.25 & 5.32 & 2.93 \\
\hline
\end{tabular}

Source: Hatton and Williamson $(1998,33)$.

Notes: These figures are for gross emigration, drawn largely from Ferenczi and Willcox (1929). Where possible, the figures include emigration to other countries within Europe. Unfortunately, data on return migration are limited. Dashes indicate data are not available.

Ireland declined from the 1860s, and from Germany and Norway it declined from the 1880s. Almost at the same time, emigration rates from Italy and Spain began a steep ascent, a trend halted only by the outbreak of war in Europe.

Various theories have been offered to explain this wide range of experience. Different studies have stressed the effects of demographic forces, relative income incentives, structural change, poverty, and backwardness in agriculture and the spread of information about emigration opportunities, among other things (Lowell 1987, ch. 2). Recently assembled data for internationally comparable real wage rates make it possible to include real wage ratios between source and destination countries to explain the emigration rates displayed in table 2.3. Real wage ratios alone, however, have only a weak inverse correlation $(-0.20)$ with gross emigration rates. Other variables must be included that systematically shifted the emigration function. One of these is the growth in the population in the emigration age group, as measured by natural increase twenty years earlier. This captures the hypothesis first put forward by Easterlin (1961) that the demographic transition in Europe drove emigration. Another variable is the share of the labor force in agriculture, reflecting structural change-a variable that the literature suggests could have conflicting effects. One argument has it that growing population pressure on limited landholdings generated emigration. Alternatively, it has been argued that rural populations were less internationally mobile than urban populations, which have often already been uprooted from their rural origins. Finally, as noted earlier, the effects of friends and relatives' providing information, supplying prepaid tickets, 
reducing the costs of job search, and lowering the cost of ethnic goods are reflected in the emigrant stock (per thousand of the population of the source country).

These variables have been included in an econometric analysis of the emigration rates in table 2.3 (Hatton and Williamson 1998, ch. 3). The result implies that a 10 percent rise in the destination to source wage ratio generates a rise in the emigration rate of 1.3 per thousand population in the origin, when controlling for the lagged dependent variable, among other variables. In the long run the share of the labor force in agriculture has a weak negative effect, suggesting that, on balance, agricultural populations were less mobile internationally than urban populations. By contrast, the lagged natural increase in the population has a powerful effect, with emigration increasing by about half of all births in excess of the number needed for a stable population. It should be noted also that this was not the result of a labor force boom pushing down the wage rate, since this effect is already taken into account through the wage ratio. Rather, it was a direct demographic spillover into emigration, which prevents an even sharper fall in the origin wage rate. Finally, controlling for the lagged emigration rate, the migrant stock abroad gives an effect that implies that for each thousand previous migrants, a further twenty were pulled abroad each year. ${ }^{17}$

One important fact that theories of emigration must explain is this: During the onset of modern economic growth in Europe, national emigration rates often rose, gradually at first, reached a peak, and then declined. This "life cycle" of emigration has been identified for a number of European countries prior to World War I. The influences just examined can help explain this pattern. Figure 2.3 presents a stylized picture of the European emigration cycle based on (quadratic) trends in the explanatory variables and the (long-run) coefficients of the emigration equation. ${ }^{18}$ Rising incomes that relaxed the "wealth constraint" provided resources to finance migration. Demographic growth, a declining share of the labor force in agriculture, and the consequent growth of the stock of previous emigrants together increased emigration by about four per thousand in the upswing of the emigration cycle. But the narrowing wage gap, as real wages in Europe converged on those of the New World, had a countervailing effect. Eventually the peak was passed as continuing real wage convergence overcame the weakening effects of industrialization, demographic boom, and the migrant stock.

These results are confined to western Europe, and they exclude eastern

17. This effect is much smaller than that typically obtained from estimation on annual time series. When one uses decade average data, a part of the friends and relatives effect will be picked up by the lagged dependant variable, because recent emigrants are likely to be the most important.

18. The trends in the explanatory variables were obtained by regressing each of them on a variable that gives a numerical value to the stage of the emigration cycle for each country (and its square). For further details, see Hatton and Williamson (1998, 47-49). 


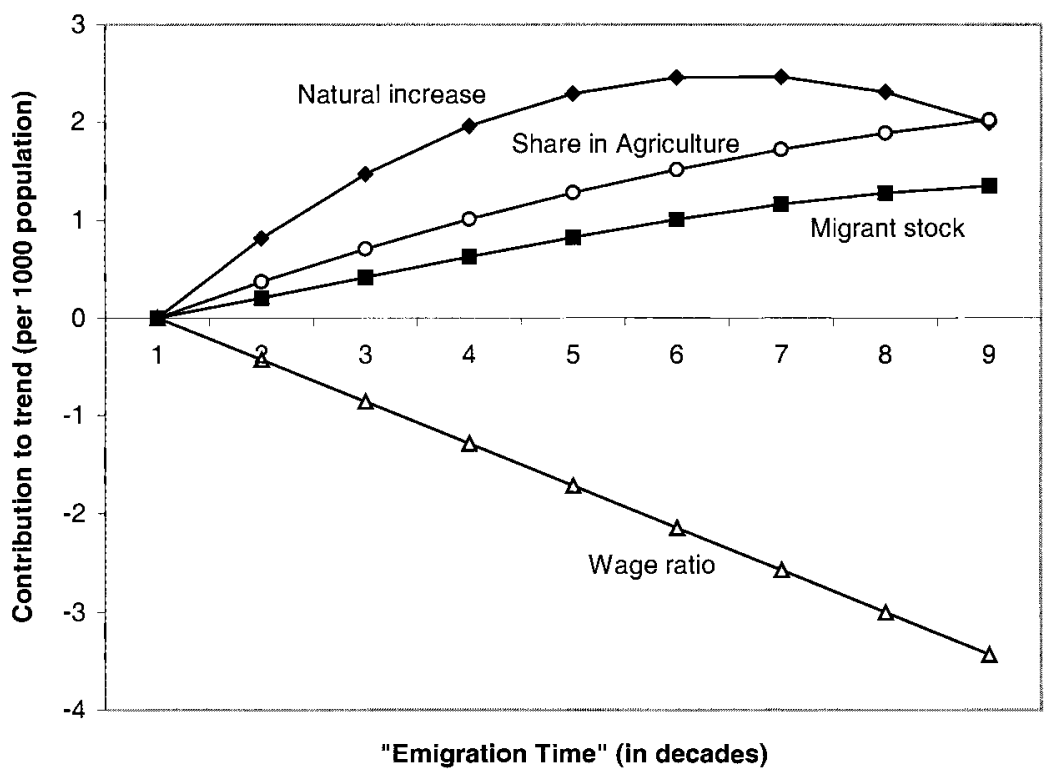

Fig. 2.3 The fundamentals driving emigration, 1850-1913

European latecomers to mass migration. In these least-developed countries and regions, despite the large incentive to emigrate, those who had the most to gain were simply too poor to finance the move. Thus, some growth in wages and income was a precondition for eastern Europe to enter into mass migration - an effect that has also been used to explain the late surge in emigration from Italy (Faini and Venturini 1994). On average, across western Europe, the poverty constraint was not important because there was no additional positive effect for the home real wage. Once a migration flow became established, the help of friends and relatives who had previously emigrated served to attenuate the poverty constraint. This would help explain why emigration could be so high from a country like Ireland and so low (at least until the end of the nineteenth century) from the south of Italy, an equally poor region. In the Irish case, the great famine of the 1840s effectively ejected a million Irish migrants, who formed a substantial migrant stock, particularly in the United States. With the poverty constraint substantially attenuated, emigration from Ireland was large in the 1850s and 1860 s but decreased as real wages in Ireland rose relative to those abroad. By contrast, in Italy, emigration increased as growing incomes at home and the growing migrant stock together gradually eased the poverty constraint.

\subsubsection{Trends in Migration Since 1950}

It seems likely that the same factors that drove mass migration in the late nineteenth and early twentieth centuries can help explain the changing 
Table 2.4

Growth of Emigration Age Group on Four Continents, 1955-95

\begin{tabular}{|c|c|c|c|c|c|}
\hline & 1955 & 1965 & 1975 & 1985 & 1995 \\
\hline \multicolumn{6}{|c|}{ Growth in previous five years of population aged 20-29 (\%) } \\
\hline Europe & 3.1 & -3.2 & 14.0 & 1.9 & -3.7 \\
\hline Latin America plus Caribbean & 11.1 & 12.3 & 19.9 & 15.5 & 8.5 \\
\hline Asia & 10.6 & 4.8 & 21.4 & 13.1 & 9.0 \\
\hline Africa & 11.6 & 10.4 & 14.4 & 17.0 & 14.3 \\
\hline \multicolumn{6}{|c|}{ Population aged 20-29/population aged 20-64 (\%) } \\
\hline Europe & 28.5 & 25.6 & 27.1 & 26.8 & 24.1 \\
\hline Latin America plus Caribbean & 35.0 & 34.9 & 37.2 & 37.8 & 35.6 \\
\hline Asia & 34.4 & 32.8 & 35.3 & 35.5 & 34.7 \\
\hline Africa & 37.0 & 36.1 & 37.4 & 38.7 & 38.6 \\
\hline
\end{tabular}

Source: Calculated from United Nations (1999, various tables).

composition of contemporary international migration. The dramatic convergence of income and earnings in Europe, especially southern Europe, during the so-called golden age from 1950 to 1973 helps explain the sharp drop in the share of European migrants to the New World (figure 2.2, table 2.2). The rise in immigration from Asia coincides with the beginnings of the "Asian miracle" of economic growth and the fall after 1975-84 in Asian growth rates. As table 2.4 shows, the growth of the emigrating age cohorts in these regions also contributed to the swings in the composition of migration. In Europe and in Asia, the growth of population aged twenty to twenty-nine slowed after 1975 (UN 2000, 61). By contrast, in Africa the population in this age group continued to surge - a fact that clearly influenced inter-African migration (Hatton and Williamson 2001).

Of course, since the Second World War immigration has been heavily constrained by quotas and other regulations. Thus, migration pressures cannot be so clearly observed, and trends in the sources of immigration may largely reflect immigration policy. The end of country quotas for Europe based on national origin and the end of the virtual ban on Asian immigration in North America and Oceania in the 1960s broke the preexisting link between allocated quotas and nineteenth-century European immigration, and opened the door to immigration from Asia (see further below). Subsequent legislation further altered the country composition of the quotas and altered the rules governing employment-based immigration.

Where these constraints were absent, economic influences clearly shaped the pattern of immigration. Jasso, Rosenzweig, and Smith (2000) analyzed those obtaining immigrant visas as husbands of United States citizens by country of origin, because spouses of U.S. citizens are not subject to numerical restriction. They found that, for the years 1972 to 1990, per capita income in the origin country had a negative effect on the number admitted, whereas origin country education had a positive effect (219). For Australia, Cobb-Clark and Connolly (1997) examined an ex ante measure of immi- 
gration: the applications for skilled immigration visas. ${ }^{19}$ They too found that real gross domestic product (GDP) ratios as well as relative unemployment rates between home and destination countries determined the flow of applicants.

Economic forces also explain ex post (policy constrained) outcomes. In their study of postwar immigration into Germany (1964-88), Karras and Chiswick (1999) demonstrate that immigration was determined by shortterm cyclical phenomena, as measured by unemployment rates, and by long-term factors as measured by incomes per capita, in both Germany and the sending countries. The lagged net migration rate, representing chain migration effects, was also highly statistically significant and important. For the United States and Canada, Kamemera, Oguledo, and Davis (2000) find evidence that incomes, unemployment, population and a variety of other economic variables influenced rates of immigration across source countries and through time. Other evidence points to the immigrant stock as the most important single determinant of the country composition of U.S. immigration (Yang 1995, 119). This reflects the fact that, since 1965, kinship to a U.S. citizen or resident alien is the single most important channel of entry.

The famines and revolutions that caused spurts of migration in the nineteenth century also have postwar parallels. In Africa civil wars typically displaced sixty-four per thousand of the population per year across international borders, whereas government crises, coups d'etat, and guerilla warfare had somewhat smaller effects (Hatton and Williamson 2001, 11). Some political upheavals have generated large flows to the developed world. The fall of Saigon in April 1975 produced a large-scale exodus of refugees from Vietnam, Laos, and Cambodia to the United States, and twenty-years later the disintegration of Yugoslavia generated large flows to the EU. Yet the number seeking asylum in developed countries is also influenced by economic factors. Applications to Germany for asylum in 1984-95 from seventeen third world countries were influenced by relative incomes and by the existing migrant stock, as well as by terror and armed conflict (Rotte, Vogler, and Zimmermann 1997). Interestingly, they also responded to economic conditions and asylum policies in France, suggesting that even asylum seekers compared alternative destinations.

Given that the same variables influenced international migration flows before 1914 and after 1950, how different are the magnitudes of the effects? There are really two questions here. First, are the unconstrained effects the same now as then? Second, how much difference does policy make? Net emigration from African countries, largely across the porous borders within Africa, provides one benchmark (Hatton and Williamson 2001). Estimates on panel data from the 1970s to 1995 indicate that a 10 percent rise in the ratio of foreign to home wages increased net out-migration by 0.9 per thou-

19. Of course, applications will be influenced by the anticipated outcome and hence by immigration policy. 
sand as compared with 1.3 per thousand in late nineteenth-century Europe. The demographic effects, although not directly comparable, are just as powerful as they were in late nineteenth-century Europe. Thus, one piece of evidence suggests that the relevant elasticities for unconstrained emigration have not changed much between the two eras.

The effects of immigration policy in attenuating economic effects can be illustrated by comparing estimates for emigrants from the United Kingdom since 1975, when they faced immigration controls, with those for 1870-1913 (Hatton 2001; Hatton and Williamson 1998, 65). The "friends and relatives" effect operates even more powerfully now than in the late nineteenth century because it has been reinforced by family reunification policies. Each thousand of the migrant stock generates between 50 and 100 percent more new migrants per year in the postwar period as compared with the period before 1914. ${ }^{20} \mathrm{By}$ contrast, the effect of source-country unemployment is between one-fifth and one-third as large, and relative income between one-tenth and one-fifth, in the recent period as they were before 1914. Thus the impact of immigration policy is to act as a filter that enhances immigrant stock effects and mutes wage and employment effects on international migration.

Such orders of magnitude are at best a very rough approximation of the effect of policy. Nevertheless, they suggest that liberalizing barriers to migration would dramatically alter the demographic landscape, partly because of the increase in responsiveness to incentives and partly because of the magnitude of those incentives. In the late nineteenth century, New World real wages were double those in western Europe; today real wages in the first world are five to ten times those in the third world. Conservative estimates of the effect of expanding the EU to include the ten central and Eastern European accession candidate countries (with income levels 40 percent of those in the EU) suggest a westward movement of 3 million people into the existing fifteen EU countries within fifteen years (Bauer and Zimmermann 1999). Liberalizing immigration from the third world is likely to produce much larger effects, both relatively and absolutely, effects that would cumulate as rising immigrant stocks in the destination and rising real wages at home relaxed the poverty constraint.

\subsubsection{Illegal Immigration}

As a result of immigration policy, the demand for visas by potential immigrants exceeds the supply made available by the immigrant-receiving countries. The result has been queues for visas of increasingly length in the immigrant-receiving countries, such as the United States, that ration, in part, by queuing, and a growing population of illegal aliens in the developed

20. Because of differences in model specification, the coefficients estimated for the two periods are not strictly comparable. In particular, the pre-1914 model includes lags whereas the post-1974 model does not. The range of magnitudes reflects the difference between using short-run and long-run coefficients from the pre-1914 estimates. 
immigrant-receiving countries. ${ }^{21}$ The illegal aliens include persons for whom the cost of obtaining a legal visa is very high, for whom it is not possible to obtain a visa, or who are jumping ahead in the queue. Whereas some of the host countries experiencing large illegal immigration are New World countries of overseas settlement, such as Australia, the United States and Canada, others are traditional countries of emigration that in recent decades have been experiencing pressures for in-migration, such as Western Europe and Japan (Organization for Economic Cooperation and Development [OECD] 2000; Weiner and Hanami 1998).

The illegal workers, for various reasons, tend to be very low-skilled (Chiswick 2001). This arises only in small part from the tilting of legal immigration opportunities in favor of highly skilled applicants. More important has been the increase in wealth and information that facilitate illegal migration even among low-skilled workers in the developing countries of Latin America, Asia, and Africa, and the greater difficulty high-skilled workers would have relative to those of low-skilled workers in masking their illegal status and in securing and maintaining employment comparable to their skill level. Low-skilled jobs are less likely to require licenses, certifications, and other documentation that might reveal one's legal status. The issue of the transferability of skills acquired in the origin is far more relevant for skilled workers than for those with few, if any, skills. Illegal aliens are less likely to bring dependent family members with them, because this would increase the probability that their illegal status would be detected. As a result, they are more likely to move back and forth between the origin and destination. For skilled workers there is a cost to this in the form of locationspecific skills depreciating when they are in the other location, whereas for workers with perfectly internationally transferable skills or, more likely, without skills, this depreciation does not occur. If illegal alien workers are largely confined to low-skilled jobs in the destinations, the wage differential between the origin and destination is much larger for low-skilled than for high-skilled potential illegal migrants.

The policy response has been threefold (OECD 2000; Chiswick 2001). One has been to increase border enforcement. Although this has reduced what would otherwise be the flow of illegal alien workers, the borders have been porous. Even island nations, such as the United Kingdom and Japan, have discovered that liberal democracies cannot seal their borders. A second response has been to improve the effectiveness of interior enforcement, mainly by imposing penalties on the employers of illegal aliens. Although employer sanctions have been adopted in many countries, including the United States (in the 1986 Immigration Reform and Control Act), they have been at most weakly enforced, as have other instruments intended to en-

21. During the earlier era of mass migration, with few restrictions on entry prior to WWI, illegal immigration was not a significant issue. The first significant illegal aliens in the United States were of Chinese origin in the 1880s, because they were the first group to be excluded by law (1882). 
force immigration law away from the borders. The third response has been to convert illegal workers into legal workers through amnesties. Many of the countries receiving illegal aliens have regularized their status, often in a series of amnesties.

The United States had the largest amnesty program. Under the provisions of the two amnesty programs in the 1986 Immigration Reform and Control Act, nearly three million individuals received legal status, primarily low-skilled workers from Latin America and their family members (Chiswick 1988). Although the combination of amnesty and employer sanctions was supposed to "wipe the slate clean" (amnesty) and "keep it clean" (sanctions), illegal immigration to the United States has continued unabated, and it is estimated that there are again about five to seven million illegal aliens, primarily low-skilled workers, living in the United States. In the late 1990s, the very tight labor market, the growing size of the illegal alien population, and the difficulty that private-sector labor unions have had in maintaining their membership base have resulted in a call from many quarters in both major political parties for another amnesty. The political pressure for another large amnesty diminished with the slow-down in the economy in 2001 and the terrorist attack by aliens in September of that year.

High-income liberal democracies are in a quandary. They offer wage opportunities that are high by the standards of the sending countries. The increase in wealth in the origin countries, the lower cost of transportation and communication - and hence the lower cost of information about alternative destinations and the ease of staying in contact with the origin - and the emergence of new immigrant enclaves have spurred incentives for lowskilled migration. Legal barriers are introduced in part to protect lowskilled native workers from this competition in the labor market, as well as in the markets for public income transfers and low-cost housing. Yet these legal barriers, including employer sanctions, are not fully effective. Liberal democracies will not adopt the draconian measures that would be needed to prevent illegal migration or discourage its permanence once it occurs. Because of the negative externalities and social problems associated with a population living and working at the margins of or outside the law, amnesties are introduced. However, rather than "wiping the slate clean," amnesties do not address the causes of the growth of the illegal alien population, but they do encourage others to become illegal migrants, because amnesties once instituted offer the prospect of future amnesties.

\subsection{The Immigrant Impact}

\subsubsection{Real Wage Convergence in the Age of Mass Migration}

One of the most important questions both in the pre-WWI era and in the post-WWII era is the effect of immigration on the earnings and incomes of 
nonmigrants, in both destination and source countries. International labor mobility, as well as the mobility of capital and tradable goods, should tend to bring about a convergence across countries in real wage rates for workers of a given level of skill in the absence of other factors that generate divergent wages. Purchasing power parity-adjusted unskilled real wage rates for Old World and New World countries show that real wage rates did indeed converge. Between 1870 and 1913 the coefficient of variation across seventeen countries fell from 0.50 to 0.43 : Among the same seventeen countries it fell from 0.45 in 1950 to 0.33 in $1987 . .^{22}$ The conjecture that mass migration played a part is strengthened by the fact that most of the convergence in the late nineteenth century is accounted for by the erosion of real wage gaps between the Old and New worlds, rather than among Old World countries or among New World countries. New World wage rates were higher than those in the Old World: by 136 percent in 1870 , by 100 percent in 1895 , and by 87 percent in 1910. In real wage terms the Old World caught up quite a bit with the New World.

Convergence was modest between Great Britain and the United States. Real wages in the United States were higher than those in Britain: by 67 percent in 1870, 50 percent in 1890, and 54 percent in 1913 (O'Rourke, Williamson, and Hatton 1994, 208). The contribution of international migration to Anglo-American real wage convergence has been analyzed using computable general equilibrium (CGE) models for the two economies calibrated for 1910. These models contain three output sectors, tradable manufacturing and agriculture and non-tradable services, and three inputs: labor and capital, which are mobile across sectors, and land, which is specific to agriculture. Under a counterfactual of no immigration to the United States and no emigration from Great Britain from 1870 to 1910, the real wage would have been 34 percent higher in the former and 13 percent lower in the latter. In the absence of the mass migrations the Anglo-American wage gap would have doubled between 1870 and 1913 rather than falling by one-fifth; instead of convergence there would have been divergence (Hatton and Williamson 1998, 213-6). ${ }^{23}$

The impacts were even greater elsewhere in the Atlantic economy.

22. The countries included are, in the Old World, Belgium, Denmark, France, Germany, Great Britain, Ireland, Italy, the Netherlands, Norway, Portugal, Spain, and Sweden; and in the New World, Argentina, Australia, Brazil, Canada, and the United States.

23. This counterfactual assumes that capital stocks in the two countries would have been those actually observed. As a result of the reallocation of labor, the return on capital would have been 24 percent lower in the United States and 13 percent higher in Britain in 1913 under the no-migration counterfactual. If, instead, the international capital market is assumed to be perfectly arbitraged, then less capital would have followed labor from the Old World to the New. As a result, under the counterfactual, wages in Britain would fall by only 6 percent and those in the United States would rise by only 9 percent. Under the no-migration assumption, the U.S.-U.K. real wage ratio would have increased from 1.67 in 1870 to 1.89 in 1913 with capital mobility, as compared with 2.47 in 1913 with no capital mobility. Hence, there would still have been divergence in Anglo-American real wages. 
Among receiving countries, such as Argentina and Australia, the laborforce-augmenting effects of immigration were larger than in the United States. And in Europe labor force losses were proportionately largest for Ireland, Italy, and Sweden. In Ireland, postfamine emigration reduced the population by a third between 1851 and 1911; in the absence of emigration it would have risen by between 50 percent and 120 percent. Even on the lower counterfactual labor force increase, a CGE model for Ireland indicates that agricultural wages would have been lower by 16 percent and nonagricultural wages would have been lower by 19 percent. Two-thirds of Ireland's catch-up on real wages in Great Britain was due to mass emigration. In the absence of emigration, the shift out of agriculture would have been less rapid and the shift from tillage to pasture within agriculture less marked (Boyer, Hatton, and O'Rourke 1994, 235).

Between 1870 and 1914 the Scandinavian countries and even Italy underwent significant real wage catch-up on Great Britain and the United States. In Scandinavia real unskilled wages grew twice as fast as those in the New World and well above the European average. In Scandinavia, emigration accounted for only a part of this spectacular catch-up; one-fifth for Sweden and Denmark and nearly one-half for Norway. Other forces, such as industrialization, trade, education, and capital formation, accounted for the rest (O'Rourke and Williamson 1997). In Spain and Portugal, by contrast, the failure of industrialization led to real wage divergence despite the effects of emigration in the other direction. Yet for the Atlantic economy as a whole Taylor and Williamson (1997) find that, in the absence of mass migrations, the international dispersion of real wage rates would have dramatically increased. Instead of falling by 9 percent, the gap between New and Old World real wage rates would have increased by 167 percent.

Real unskilled wage rates were not the only factor prices that converged in the late nineteenth century, nor was migration the only source of convergence. As labor was transferred from the Old World to the New, land prices (and rents) boomed in the New World and stagnated in the Old. The integration of global commodity markets also contributed: A dramatic decline in ocean freight rates and overland rates led to a trade boom. The New World exported land- and resource-intensive goods and imported laborintensive goods just as the Heckscher and Ohlin model of international trade would have predicted. For this reason, too, the wage rental ratio fell in the New World and rose in the Old World, with clearly identifiable consequences for trends in inequality. As we shall see, slow growth in real wages and rising inequality in the Americas and Oceania contributed to what Williamson (1998) has called the "globalization backlash" in the form of rising barriers to both trade and migration.

\subsubsection{Labor Market Impacts in the Postwar Period}

In the post-Second World War period, rising concern about immigration has been accompanied by a proliferation of studies aimed at measuring the 
labor market impact of immigration, particularly in the United States. The presumptions have been the same as those that have guided research for the epoch just discussed. That is, the increase in labor supply brought by immigration should reduce the earnings of factors that are close substitutes for immigrants, such as native-born labor, and it should raise the incomes of cooperating (complementary) factors, such as capital, land, and - if the immigrants are unskilled - skilled labor. ${ }^{24}$ But the typical findings have been very different.

It is said that immigration policy is made at the national level, but the direct impacts are largely felt in a small number of local areas. Thus, a characteristic of immigrants in the major immigrant-receiving countries is a very high degree of immigrant and ethnic geographic concentration. For example, there was a very high degree of geographic concentration within the United States among the foreign-born at the turn of the twentieth century, just as there was a century later. In 1998, 9.9 percent of the population of the United States was foreign born. Of the foreign-born, 71 percent lived in only six states, with 30 percent in California (24 percent of the state's population), 14 percent in New York (20 percent), 9 percent in Florida (16 percent), 9 percent in Texas (12 percent), 4.5 percent in Illinois ( 9.9 percent), and 4.5 percent in New Jersey (15 percent). The geographic concentration of the foreign-born is even more intense when data are analyzed on a county basis (Chiswick and Sullivan 1995). In the United States in 1990, 8 percent of the population was foreign born. Among the 3,145 counties, in 1,521 counties (48.4 percent) the proportion foreign born was 1 percent or less; in 1,464 counties (46.6 percent) it was 1-8 percent; in another 109 counties ( 3.5 percent) it was $8-16$ percent; and in only 47 counties ( 1.5 percent) it was 16-45 percent (Chiswick and Sullivan 1995). Dade County, Florida, had the record of 45 percent of its population foreign born.

Not surprisingly, numerous studies have attempted to isolate the effects of immigration on wage rates or wage changes by exploiting this cross section's variation. Of the many studies, most find almost no effect of the percentage of foreign-born on native-born wages (Greenwood and McDowell 1994; Borjas 1994). The largest effects found suggest that a 14 percent increase in the share of foreign-born reduced the wage of low-skilled nativeborn workers by less than 1 percent (Altonji and Card 1991). Even this seems surprisingly small. But the total effect of immigrants on the economy would be the same as the local impact only if local areas were (relatively) closed economies. The mobility of labor, goods, and capital across regions and localities within a destination country will produce a tendency toward price equalization that would preclude observing a relationship between immigration and wages and prices across local areas (Chiswick 1993).

There is abundant evidence that the settlement patterns of immigrants

24. For models of the impact of immigration on the destination labor market, see Chiswick, Chiswick, and Karras (1992) and Chiswick (1980, 1998). 
depend on economic incentives. A number of studies have examined the intended destinations of immigrants arriving in the United States and Canada at the turn of the century (Dunlevy 1978; Green and Green 1993; Dunlevy and Saba 1992) and in more recent decades (Bartel 1989; Bartel and Koch 1991). They find that immigrants systematically migrated toward states with relatively high earnings. This responsiveness to economic incentives would tend to undermine any negative correlation between earnings and the concentration of immigrants. But immigrants were guided by other influences as well, settling first in ports of entry and in areas with a larger stock of previous immigrants from the same country of origin. As a result, the geographic distribution of immigrants then and now differs significantly from that of the native-born.

The skewed distribution of immigrant settlement influences internal migration among the native-born. An interesting "natural experiment" was the Mariel boatlift in 1980, which brought an influx of 45,000 Cubans into Miami, equivalent to 7 percent of the Miami labor force. Card (1990) found that this influx had almost no long-run effect on the size of the city's labor force or on the wages of competing groups of whites, blacks, and other Hispanics because of the mobility response of the native-born and previous immigrants. Filer (1992) examined native-born migration patterns across 272 localities in 1975-80. He found that, after controlling for local labor market characteristics, an influx of foreign-born workers crowded out native workers one for one..$^{25}$ There is also evidence along these lines for late nineteenth-century America. In the states comprising the northern quarter of the country (New England, the mid-Atlantic, and the east-north-central regions), changes in the number of immigrants across census years between 1880 and 1910 displaced the native-born either by generating westward outmigration or by averting internal in-migration. ${ }^{26}$ Every additional $100 \mathrm{im}-$ migrants to the northeastern states displaced an estimated forty of the native-born population (Hatton and Williamson 1998, 168).

This discussion suggests that markets do respond to the impacts of immigrants and that the impacts are mitigated in the immigrant-receiving areas and are disseminated throughout the economy. Although immigrants may be geographically concentrated, their impacts are distributed throughout the economy, even to regions or sectors where there are no immigrants. It also suggests that an analysis of the impact of immigrants in an advanced industrial economy should focus on their effects on economywide factor proportions. In advanced industrial economies it also requires the explicit recognition of the heterogeneity of labor, in particular, the distinction between high-skilled and low-skilled labor.

25. Findings like these have been contested, most recently by Card and Di Nardo (2000).

26. The large internal migration of blacks from the rural south to the urban northern and western cities had to await both low urban unemployment in the destinations and low immigration from Europe. 
The relative supplies of high-skilled and low-skilled native workers and immigrants differ over time, as does the definition of what constitutes a skilled worker. In an economy with two types of labor-say, high-skilled or professional workers and low-skilled nonprofessional workers-and a third factor, capital, the impact of immigration becomes more complex. If different types of labor are not strong substitutes for each other in production, the immigration of one type of labor can not only affect its wages, but also affect in an opposite direction the wages of complementary types of labor (Chiswick 1980, 1982; Chiswick, Chiswick, and Karras 1992). The immigration of low-skilled workers (e.g., Mexican laborers into the United States or Turkish laborers into Germany) would tend to depress the wages of all low-skilled workers in the destination but raise the wages of the complementary factors, including high-skilled workers and capital. This would increase wage differentials by skill and earnings inequality. On the other hand, the immigration of high-skilled workers (e.g., South Asian computer programmers into the OECD countries) would tend to lower the wages of high-skilled workers but raise the returns to low-skilled workers and the return to capital.

An interesting "natural experiment" with regard to the impact on relative wages of exogenous immigration that differed sharply by skill level in different periods in the context of a three-factor model is offered by Israel. There was a relatively large scale immigration of Jews from the 1930s through the 1960s into the Jewish economy of Mandatory Palestine/Israel that was primarily exogenous to the wages in the destination and was large relative to the destination economy. ${ }^{27}$ These migrants were refugees and displaced persons, whose choice of destination was motivated by religious and ideological factors, as well as constraints on alternative destinations. Relative to the size of the preexisting Jewish economy in Mandatory Palestine, during the 1930s there was a large Jewish refugee flow with professional and other high levels of skill from Germany and central Europe into a capital-poor economy. The result was a decline in the relative wages of skilled workers, a decline in the rate of return from skill, and a very small earnings inequality. Following independence (May 1948), Israel experienced a relatively even larger influx of refugees as Holocaust survivors (whose skills and health had depreciated) and primarily very low skilled Jewish refugees from Arab countries in North Africa and the Middle East, from Morocco to Yemen. The large immigration of low-skilled workers depressed the relative wages of low-skilled workers, increased the rate of return from schooling, and increased earnings inequality (Chiswick 1974, 97-101). More recently, starting in 1989, there was a large exogenous influx of relatively high skilled Jewish refugees into Israel from the various parts of the former Soviet Union, referred to collectively as Russian Jews. This inflow increased the Israeli 
population by 7 percent in two years (1990 and 1991) and by 12 percent in the first half of the 1990s (Friedberg 2001). The previous upward trend in real wages halted in the early 1990s as the Israeli labor market absorbed the increased labor supply, but returned later in the decade. Although a large proportion of the Russian Jewish immigrants were in high-skilled jobs in the former Soviet Union, it took time for them to learn Hebrew and for some to transform their preimmigration skills into high levels of skill relevant for the Israeli labor market, and for others, particularly older immigrants, this transformation did not and may never take place. Thus, by the late 1990s, although some were able to join the high-skilled ranks in the labor force, others remained in lower skilled jobs. The Russian Jewish immigrants helped fuel the growth in Israel's high-technology sector ("Silicon Wadi") during the 1990s, but because of their wide distribution across skill levels relevant for the Israeli economy, they had mixed effects on the relative wages in skilled occupations.

Economists have been slow to recognize that effects such as these must be measured at the economywide level. One recent study based on economywide factor proportions estimates that about half of the increase in the wage gap between those with less than and those with more than twelve years of education in the United States from 1979 to 1995 was due to immigration (Borjas, Freeman, and Katz 1997, 53). Between the mid-1890s and World War I the wage gap between the skilled and the unskilled also grew, and this has been associated with the flood of "new" immigrants. But the evidence suggests that it owed more to unbalanced derived demand growth favoring skilled workers than to unskilled immigration (Williamson and Lindert 1980, 208-9, 236).

\subsubsection{Adjusting to Migration}

Economists have taken a long detour over assessing the effects of immigration on labor markets. Most of the work has focused on the United States, and there has been little consideration of the impacts on sending countries in the second era of globalization. Nevertheless, two things are clear. First, in both sending and in receiving countries there have been both gainers and losers from migration. Thus, migration's main direct effects have been on the relative scarcity of factors, on relative factor prices and on income distribution. Second, those effects have been different in the two eras of mass migration. Among immigrant-receiving developed economies the foreign-born are a smaller share of the population now than they were in 1913, so their effects should be smaller. Adjustments in other markets, however, could also have attenuated or enhanced the impacts differently across the two periods.

One development is the integration of capital markets examined in this volume by Obstfeld and Taylor (ch. 3). Before 1914 capital and labor flowed in the same direction in the Atlantic economy: from the Old World to the New. Immigrant-induced growth in New World labor supply drove up the 
return to capital and generated capital inflows, whereas the opposite occurred in the Old World. As a result the marginal product of labor fell less in the New World and rose less in the Old World than it would have in the absence of capital market integration. In the computable general equilibrium framework, with perfect capital mobility and no international migration since 1870, the U.S. real wage in 1910 would have been 9.2 percent higher than it actually was; capital would have retreated to Europe. As noted earlier, with no capital mobility the real wage would have been 34 percent higher in 1910, a big difference. For Great Britain, perfect capital mobility cuts the effect of emigration on the real wage by half, and for the Atlantic economy as a whole, by three-quarters (Taylor and Williamson 1997, 47).

In the late nineteenth century, the endogenous flows of international capital did not completely offset the effect of migration on wage rates. The main reason is because of the importance of land, fixed in supply and specific to one sector: agriculture. Thus, one reason immigration impacts are smaller now than a century ago is that agriculture and other land-intensive sectors are now a much smaller part of developed economies. In the United States the share of the labor force in agriculture and mining fell from 43 percent in 1890 to 3 percent in 1990, in Germany it fell from 44 percent to 4 percent, and in Great Britain it fell from 22 percent to 3 percent.

What about trade in goods and services? In the Hekscher-Ohlin model, trade between countries reflects their factor endowments and is therefore a potential substitute for migration. In a frictionless, perfectly competitive environment, migration-induced changes in relative labor intensities could alter trade patterns and, through Rybczynski effects, leave factor prices unaltered. If such effects mattered, we should see trade and migration moving in opposite directions: Migration should make endowments more similar across countries and thus reduce the basis for trade. But the crude correlation suggests it did not. Migration and trade both expanded after 1850, as they did again after 1950 (see Findlay and O'Rourke, ch. 1 in this volume). An analysis of the determinants of trade volumes in the Atlantic economy in the (relatively) free trade era before 1913 suggests that migration was not an important influence (Collins, O'Rourke, and Williamson 1999). It seems likely, however, that the effects on trade were overwhelmed by other forces that drove both trade and migration.

Alternatively, relative factor proportions could have determined the direction of technical change. If endogenous biases in technical change responded to cross-country differences in factor intensities, then these would push in the same direction as migration by augmenting the scarce factor. Rather inconclusive debates point to labor-saving innovation in midnineteenth-century America and to skill-saving technical changes in the late nineteenth century, with neutral or opposite effects in the Old World. By contrast, there is widespread agreement that skill-biased technical change has widened the wage distribution in Great Britain and the United 
States since the 1960s. Here, the debates are about the ultimate causes, the permanence, and the magnitude of the effects of skill-biased technical change, rather than about its general direction..$^{28}$ Whether endogenous or not, relative biases in technology probably compounded the effects of migration on factor rewards in both eras.

What about endogenous changes in the composition of migration itself? In both mass migration eras there have been important streams of human capital incorporated in workers who were highly skilled by the standards of the day. In the eighteenth century the migration of European artisans was frequently subsidized to bring high levels of skill to North America. These artisans substituted for the importation of the products that they would have produced in Europe and exported. With the Industrial Revolution occurring in Europe in the nineteenth century, the new version of high-level manpower, skilled industrial workers, flowed from Europe to the countries of overseas settlement to advance the development of industry in North America and elsewhere. From 1820 to 1910 "entrepreneurs" were a higher proportion of the foreign-born than of the native-born, although that difference was declining (Ferrie and Mokyr 1994, 130).

With the development of science and technology in North America, home-grown human capital provided much of the highly skilled manpower. Skilled workers came as refugees, especially from Germany and other parts of Europe in the 1930s and 1940s, while others formed part of normal migrant flows, following the usual incentives. Recent evidence for the United Kingdom suggests that the increase since the 1970s in the returns to skill, as reflected in the widening income distribution, increased the skill content of immigration (Hatton 2001). But this was in the presence of skill-selective immigration policies. In the late nineteenth century and in the late twentieth century the incentive effects of returns to skill on the composition of migration have often been swamped as low-skill countries have entered into the upswing of their emigration cycles.

A more important influence on the skill composition of migration is the immigration policies of major receiving countries. Although the 1965 amendments to U.S. immigration law emphasized "kinship" to a U.S. citizen or resident alien for rationing admissions, they explicitly included a small skilled-professional-worker category. Canada, Australia, and New Zealand placed far greater emphasis on the applicants' skills in the rationing of immigration visas. In the late 1980s, but especially in the 1990s, changes in U.S. immigration policy widened the scope for the admission of

28. Consider the useful distinction between "worker (task-performing) efficiency" and "allocative (decision-making) efficiency." Technological change that is neutral with respect to high and low levels of worker efficiency will initially appear to be skill biased because workers with more human capital also have greater allocative efficiency and are better able to quickly and efficiently exploit the new technology. Whether the observed skill bias in the new computer-related technology is permanent or temporary will depend on whether it only appears to be so because of the temporary advantages of those with greater allocative efficiency. 
skilled workers as permanent resident aliens (as in the Immigration Act of 1990) and by creating and expanding a series of "temporary worker" programs for high-level manpower. Temporary worker categories were created or expanded for registered nurses (H1-A and H1-C visas), trainees (work experience for highly skilled workers; $\mathrm{H} 3$ visas), workers with extraordinary ability ( $\mathrm{O}$ visas), and athletes and entertainers ( $\mathrm{P}$ visas); and under the umbrella of the North American Free Trade Agreement, an exchange program was established for high-skilled workers, primarily between the United States and Canada. The best known of these temporary worker programs is the H1-B visa, for workers with "specialty occupations" admitted on the basis of professional education, skills, or equivalent experience. The H1-B visas have been used primarily in the high-technology and higher education industries, upon employers' satisfying the U.S. Department of Labor that after making a good faith effort the employer has found no qualified worker with a legal right to work in the United States who is available for and willing to take the job at prevailing wages. ${ }^{29}$ The United States is not unique in the inflow of high-skilled workers from other developed (OECD) countries and from the developing countries, particularly Asia. Many of the other developed OECD countries are also importing high-technology workers from each other and from the developing countries. ${ }^{30}$ Whether they are admitted as temporary or permanent workers, the duration of their stay is likely to be determined by their own wishes, rather than the initial intent of their host countries. Among high-technology workers in particular, because of the rapid spread of information and the industry's use of English as the lingua franca, there appears to be emerging a single worldwide labor market in the developed countries, regardless of the worker's country of origin.

\subsection{The Political Economy of Immigration Control}

\subsubsection{Rising Barriers}

Early in the age of mass migration, controls on migration were either absent or largely ineffective. But as the numbers mounted toward the end of the nineteenth century, receiving countries became increasingly concerned

29. The entrants under the temporary visa program for workers and trainees (H's, O's, and P's), as well as the professional workers who enter under the North American Free Trade Agreement (NAFTA) increased from less than 75,000 in 1985 to over 430,000 in 1998, and the numbers have grown since then. Their accompanying spouses and children increased from over 12,600 in 1985 to nearly 105,000 in 1998 . Thus, in 1998 these "temporary" migrants totaled over 535,000 individuals, rivaling the 660,477 persons admitted as "lawful permanent resident aliens" (legal immigrants) in the same year.

30. In the decade of the 1990s, following the collapse of the Soviet Union in 1989, approximately one million Soviet Jews and their family members emigrated to Israel, raising the population to six million. This was an unusually high-skilled mass migration, dominated by doctors, engineers, and computer specialists. In addition to depressing the relative wages of highly skilled workers, the influx spurred the development of "Silicon Wadi," the Israeli hightechnology sector. 
with controlling the flow. The door to immigrants was closed gradually in stages rather than being slammed shut, as is sometimes supposed. The shift away from pro-immigration policies began in New World countries with the regulation of shipping companies and emigration agents, the banning of contract labor, and the banning of those who were likely to become "public charges" or were considered undesirable because of their race or origin. The positive inducements to immigration offered by some countries also began to diminish. Argentina abandoned its subsidies in 1890, as did Chile in 1891. From the 1880s, Australia and New Zealand progressively reduced their levels of assistance, policies that were revived briefly with subsidies from the British government under the Empire Settlement Act of 1922.

In the United States, the Chinese were excluded by an act of 1882 and the Japanese by a "gentlemen's agreement" in 1908; all Asians (other than those from the Middle East) were excluded under the "Asiatic Barred Zone" in 1917. After several attempts at legislation, the United States introduced a literacy test, in any language, in 1917, although illiterate relatives (spouse and children) of a literate admitted immigrant were also given visas. This was followed by quotas based on national origins in 1921 and 1924, aimed against immigrants from southern and eastern Europe. ${ }^{31}$ A literacy test was introduced in Natal in 1897 and was followed by similar tests introduced in Australia (the so-called "white Australia policy," 1901), New Zealand (1907), and Canada (1910). ${ }^{32}$ Similar patterns of escalating restrictions were adopted in South Africa and Brazil, culminating in quota systems in 1930 and 1934, respectively. Even the British dominions adopted severe restrictions limiting immigration from Britain: Australia in 1930, New Zealand in 1931, and Canada in 1932.

Post-WWII immigration policies are even more heterogeneous, but for major receiving areas, they can be classified into four, often overlapping, regimes. The first of these is the guestworker systems of the early postwar years. The best known is that of Germany, where wartime forced labor was replaced first by inflows of ethnic Germans displaced from territories lost in the east and then, through a series of bilateral agreements, with guestworkers from southern Europe and Turkey. ${ }^{33}$ Between 1960 and 1973, when recruitment was abruptly stopped, about a million a year were recruited. Less

31. The quotas established in 1921 restricted the annual number of immigrants to the number from each country recorded in the 1910 census. Those enacted in 1924 (effective in 1929) allowed 2 percent of the number of each nationality present in the 1890 census, which predates much of the surge of emigration from southern and eastern Europe.

32. The white Australia policy involved a dictation test (as in Natal) in which the prospective immigrant was required to write out a dictated passage in a European language chosen by the immigration officer. In practice this meant English, so that the white Australia policy was really a British Australia policy. On this and other regulations, see Daniels (1995).

33. Initially, seasonal workers were recruited from Italy; subsequently, agreements were signed with Greece (1960), Spain (1960), Turkey (1961), Portugal (1961), and Yugoslavia (1968). For a recent study of the guestworker experience, see Herbert and Hunn $(2000,189)$. 
well known and on a smaller scale were guestworker programs in France, Belgium, and the Netherlands, all of which were abruptly halted as a result of the oil price increase and recession in 1974. In the New World, too, there was active recruitment of low-skilled temporary migrants. Under the Bracero Program in the United States (1942-64), initiated during the tight labor market during WWII, workers were recruited, chiefly from Mexico, and mainly to work in agriculture, under short-term contracts. And, as we have seen, new guestworker streams became established in the Persian Gulf.

Second, there was a dramatic shift in the major immigrant-receiving countries from systems based on national origins to worldwide quotas. In the United States, prior to 1965, 70 percent of the Eastern Hemisphere quota was allocated to the United Kingdom, Ireland, and Germany. The 1965 Amendments to the Immigration and Nationality Act broke the link between allocated quotas and past immigration, ended the virtual ban on immigration from Asia, and introduced a quota for the Western Hemisphere. ${ }^{34}$ Similarly, preferences for British, Irish, and other northern European immigrants were abolished in Canada in 1962. In Australia the "white Australia policy" was abandoned, gradually in the 1960s, and then decisively in 1973, although in New Zealand it had to wait until 1987.

It is not likely to be mere coincidence that the three major Englishspeaking countries of overseas settlement abandoned their pro-northwest European immigration policies at about the same time. High rates of economic growth in these countries and the decline in emigration from Europe due to the tight labor markets in Western Europe were important factors. The growing civil rights movement in the United States was also in sharp contrast to the openly racist "national origins" quota system still in effect since the 1920s. However, another aspect of globalization may have been important. Much of Africa and Asia was gaining independence from the former colonial powers of Western Europe. Clearly racist immigration policies in the United States, Canada, and Australia did not sit well with the newly independent countries that were to become increasingly important trading partners and neutrals or participants in the Cold War with communism. ${ }^{35}$

34. The system introduced in 1965 allowed an annual limit of 20,000 for immigrants for each Eastern Hemisphere country, up to a total of 170,000 , and a numerical limit of 120,000 visas per year for the Western Hemisphere. In 1976 the same overall country quota and system of preferences was extended to immigrants from the Western Hemisphere, and the two hemispheric ceilings were combined into a worldwide quota. Immediate relatives of the U.S. citizens (e.g., the spouse, minor children, and parents) were not subject to numerical limit and were not charged to the quotas. Legislation enacted in 1990 modified the latter system by limiting some of the kinship visas (in particular the sibling category) the larger the number of immediate relatives admitted.

35. In the United States, the 1965 amendments replaced the "national origins" quota system with a system largely based on kinship to a U.S. citizen or permanent resident alien. The intention was to replace an obviously racist system with one that would appear racially neutral but would largely replicate the countries of origin of the immigrants who came to the United 
Third, humanitarian considerations were given an important role. The widening in the range of source-country refugee admissions was often followed by policies that strengthened rights of immigration through family reunification. These were underpinned by a growing body of international agreements through organizations, such as the UN and the International Labor Organization (ILO), aimed at protecting human rights. ${ }^{36}$ Humanitarian agreements such as the 1951 Geneva Convention on Refugees, to which a growing number of countries subscribed, also opened the door from the 1980s to an increasing number of asylum seekers. ${ }^{37}$ In most countries of Western Europe, North America, and Australia, where primary immigration was limited by quotas or caps on work permits, some categories of family reunification and refugee admissions were unlimited in principle, subject to the relevant conditions.

In addition, a number of countries gave amnesties to illegal immigrants, notably France (1981-82), Argentina (1984), Italy (1977-78), and the United States (1986; Stalker 1994, 152), with a further wave among EU countries in the 1990s. At the same time, however, they began to tighten up on the conditions for family reunification and on the generosity toward asylum seekers and illegal immigrants. In Europe, countries like France and Germany revised their domestic laws and ordinances, and the EU's summit meetings in Dublin (1990) and Tampere (1999) sought mechanisms to regulate the flow of asylum seekers. Several countries, including the United States (1986), introduced sanctions against employers who knowingly hired illegal aliens. The enforcement of these penalties on employers has, however, been very weak.

Finally, as we have seen, OECD countries have sought to allocate the diminishing share of visas going to primary immigrants increasingly on the basis of skills. A skills component was introduced into the Canadian points

States in the previous decades (Daniels and Graham 2001, 43-44 and 147-48). For a variety of reasons this was not to be the case, and Mexican and Asian immigrants, rather than European immigrants, have become the largest beneficiaries of the kinship visas (Chiswick and Sullivan 1995).

36. The UN Declaration of Human Rights (1948) and the International Convention on the Elimination of All Forms of Racial Discrimination (1965) were followed by other agreements encouraging the protection of refugees and affirming the primacy of the family. From the 1960s a series of ILO conventions provided for equal treatment of nonnationals. Although not all countries subscribed to these, a number of regional associations such as the EU, Mercosur (South America), NAFTA (North America), and the Economic Community of West African States (ECOWAS) enunciated rights for migrant workers. On these and other agreements, see UN $(1998,71-76)$.

37. For example, in the postwar period the United States provided for the admissions of refugees from Communist countries and certain parts of the Middle East, but not from elsewhere. Under the Refugee Act of 1980, however, the United States abandoned its largely "communist country only" policy and adopted the UN language of defining refugees as persons with a "well-founded fear of persecution" for political, religious, ethnic, or several other reasons, regardless of the communist orientation of the regime in the origin. The result was an increase in the range of source countries and refugee admissions. 
system in 1967, which was later given more weight. Australia and New Zealand also shifted further toward selecting on the basis of education and experience and away from specific occupations (see Winklemann 2000). These systems award points for education, experience, language skills, and being in a prime age group, and they also include categories for business migrants bringing capital or intending to start a business. Almost alone among the developed countries, the United States sharply increased its employment-related immigrant visas in 1990, more than doubling what had been a small skill-based employment visa program. Although a Canadianstyle point system was seriously considered by Congress in the late 1980s, rather than causing a move to a point system, the 1990 Immigration Act retained the U.S. employer-petition, job-specific (job-targeting) method of rationing skill-based visas. Cumbersome administrative procedures (which require that employers demonstrate to the U.S. Department of Labor that there is no qualified person with a legal right to work in the United States willing to take the job at prevailing wages) have limited the use of the employment-based visas, and the quotas have not been filled.

\subsubsection{Explaining Policy Regimes}

Dramatic shifts in policy and differences among countries have often been explained on a purely ad hoc basis, but a literature has developed that tries to systematically account for policy formation. Interest-group politics link immigration policy outcomes with the actual or perceived effects of immigration, past or prospective, on different interest groups or constituencies. If those who stand to gain are politically powerful, then immigration policy should be less restrictive than if the losers wield the most political muscle. It does not follow from this that economic determinism is the only thing that matters. Politics also matter, and in several different ways. First, shifts in the political balance, either through the adoption of democratic institutions or through the extension of the franchise, could tip the balance in favor of immigration control. This, together with the weakening of landed interests and the growing influence of labor, particularly unskilled labor since the mid-nineteenth century, should have shifted the political balance against immigration, as it did in the early twentieth century. Second, since economic interests may not be the only ones that drive immigration policy, attitudes to immigration and racial prejudice may matter independently. Third, ethnic politics may be important, where members of an ethnic group seek to encourage the immigration of those who will add to the group's size and power. Fourth, political elites may be captured by particular interest groups, or they may be sufficiently strong (or impervious) to pursue strategic aims independently of their political mandate. The bottom line is that the same economic changes may translate into different policy outcomes across countries and over time.

To explore the economic correlates further, Timmer and Williamson 
(1998) constructed an index of immigration policy openness for six countries between 1870 and 1930. They explain declining openness by variables representing the gains (or losses) from immigration for different interest groups. For Argentina, Brazil, Canada, and the United States the ratio of unskilled wage rates to GDP per capita was associated with more open immigration policies. The resulting mass migration, by increasing the return on nonlabor assets, and shifting New World income distributions away from labor, contributed to the policy backlash that began in the late nineteenth century. The backlash also depended on the volume and composition of immigration itself. In Argentina and Australia, with relatively homogeneous immigration streams, it was the rising share of foreign-born that mattered; in Canada and the United States, where immigrant origins were more diverse, it was immigration from low-wage countries that differed in ethnicity and religion from earlier immigrants and the native population that helped close the door (Timmer and Williamson 1998, 752).

The effects identified by Timmer and Williamson (1998) also seem relevant to the partial reopening of the immigration door in the early postwar period - but in reverse. The rapid growth of real wages, narrowing income distributions, diminishing skill differentials, and falling foreign-born shares should all have eased the pressure for restriction. This was reflected in broadening access to previously excluded groups. European recruitment policies of the 1960s, the United States Immigration Amendments of 1965, and Australia's abandonment of its British-only policy were each preceded by a slowdown in the most desired source of immigrants. Thus, Germany turned to southern Europe after the Berlin Wall went up; the United States changed its policy as economic growth, demographic decline, and the barriers to emigration from the countries controlled by the Soviet Union stanched the flow of Europeans; and Australia dismantled its British-only policy as the numbers fell short of the 1 percent target.

Macroeconomic conditions also matter. If, at times of high unemployment, immigrants simply add to the unemployed pool or displace natives, then no one benefits and some lose. All groups then have an interest in tightening immigration policy. Shughart, Tollinson, and Kimenyi (1986) found that unemployment was a key determinant of policy restrictiveness in the United States since the turn of the century, as reflected in either deportations or required departures relative to the immigrant flow. Money (1999, ch. 2) found unemployment to be the key explanator of restrictiveness in OECD countries since the 1960s. Casual empiricism also supports these findings. Sharp increases in restrictiveness took place in Australia and Canada in the early 1930s, and the abrupt ending of guestworker policies in Europe in 1974 surely owes much to deteriorating economic conditions. In postwar Australia, the unemployment rate has been found to be the single 
most important determinant of the annually announced targets for immigrant intake (Wooden et al. 1994, 304). ${ }^{38}$

\subsubsection{Political Interest Groups and Coalitions}

Globalization forces can explain why the immigration door to the New World began to close in the late nineteenth century. That is, they help explain changes in immigration openness, but not necessarily the level of restriction prior to the 1930s. After all, these globalizing forces can be observed from the middle of the nineteenth century. In economies where labor was the source of income for the many, and capital and land were concentrated among the few, one might have expected the door to close earlier and more firmly. One reason is that the democratic franchise was often limited to male owners of property. Another is that agricultural or manufacturing interests often formed powerful political coalitions. A third reason is that opposition to immigration was balanced by wider national interests (Foremen-Peck 1992).

In countries like Argentina and Brazil, landowners and planters were the dominant forces behind immigration policy. In the case of Brazil, the plantation economy was supplied by slave labor until midcentury, but, under external pressure, slave imports ceased in 1852 and slavery was eventually abolished in 1888. With the prospect of rapidly increasing labor costs, the São Paulo coffee planters used their political influence over the government of São Paulo and over the central government to lobby successfully for the provision of free passage for immigrants from southern Europe. ${ }^{39}$ As a result, profits of the fazendeiro were enhanced, although the gains to workers "appear to have been negative" (Leff 1982, 68). But with the growth of manufacturing and urban expansion from the turn of the century, the planters' power to promote mass migration waned and finally evaporated.

By contrast, Canada and Australia were characterized by more representative government, by ongoing imperial ties, and above all by developmental states. Both countries were thinly populated and both adopted nation-building policies that involved encouraging immigration but re-

38. As in other countries, such as Canada, changes in immigration targets have often been the subject of administrative control rather than requiring legislation as in the United States. However, even in the United States administrative rules barring persons who were likely to become a public charge were tightened in the 1930s (and more stringently invoked to reduce the immigration of German Jews), and the requirements for labor certification for the employment-based visas in the post-WWII period have a counterycyclical effect.

39. Between 1885 and $1913 £ 11$ million was spent in subsidies to secure this labor supply. Leff $(1982,61)$ argues that providing free passages was more profitable to planters than paying higher wages to attract more migrants. There are also reasons why planters would have preferred government subsidies to private subsidies, even though government revenues came mainly from the coffee sector. One is that the implied pooling overcomes the free-rider problem, that is, the problem of tying the migrant to the employer who financed the move. Another is that some proportion of the costs would be borne by other taxpayers. 
stricting it to (relatively homogeneous) northern Europeans. In Canada the National Policy from 1872 aimed both to populate the prairies through immigration and to industrialize through tariff protection. In Australia, where agriculture was relatively more important, where landholding was more concentrated, and where (as in new South Wales) the squatters were a powerful interest group, policy was more pro-immigration. But the foundation of the Australian Federation in 1901 diluted these interests and led to the more restrictionist white Australia policy.

In Europe, policy toward emigration also varied, although attempts to restrict emigration in countries such as Belgium, Italy, and Switzerland were largely ineffective. Where landed interests were most powerful, such as in Russia, emigration was illegal and the law was more strongly enforced. In labor-abundant Great Britain, the declining influence of landed interests in the early nineteenth century and the development of the Empire ensured a strongly pro-emigration policy. And the rising influence of labor in the late nineteenth century saw the introduction of the first restrictions on immigration in 1905.

Although the pre-1930 policies of most countries would seem to fit into a loose political economy framework, some observers see the United States as an exception, at least before 1917. Limited imperial and nation-building imperatives (post-Civil War), a wide democratic franchise, a burgeoning industrial/urban sector, and widespread opposition to mounting immigrant flows would seem to predict rising barriers to immigration. The myth, if not the reality, of the westward movement of the frontier and of cheap land provided scope for more immigrants, at least until the close of the nineteenth century, as did the expanding industrial and mining sectors of the economy. ${ }^{40}$ The rise of nativism in the pre-Civil War period resulted in individual disqualifiers, that is, immigration restrictions against "socially undesirable" individuals, including those who were criminals, immoral, or likely to become a public charge. In the postbellum period, nativist sentiment emerged again but was successful only in restricting the immigration of Chinese laborers and, later, other Asian workers. On the whole, however, the door remained open for Europeans until the 1920s.

In 1897, the U.S. Congress came within two votes of introducing the literacy test, but legislation was delayed for a further twenty years. Goldin (1994) set out to explain why. She found that in the House of Representatives votes in favor of the literacy test in 1915 were positively associated, across cities, with falling wage rates, with population density, and with the proportion of immigrants in the population. Thus, globalization forces

40. Foreman-Peck (1992) speculated that American exceptionalism could be explained by the fact that most immigrants were unskilled and that unskilled immigrant labor might be a complementary factor to native-born skilled labor. However, his production function estimates for U.S. manufacturing in the 1890s indicated that native- and foreign-born labor were not complements — so the anomaly remains. 
were at work, but they were mediated by interest-group politics. With the high unemployment of the 1890s, the alignment of nativist and labor interests generated almost enough votes to get the literacy test passed into law. As prosperity returned, employers returned to a strong pro-immigration stance. But now the South became more anti-immigration, partly to protect its strength in Congress. Finally, the weakening of the urban pro-immigrant vote, driven by rising isolationism stimulated by World War I, ensured sufficient support to pass the literacy test into law in 1917. The literacy test, however, was literacy in any language. It was thought that this would advantage potential immigrants from the more literate countries of northwestern Europe and disadvantage immigrants from the less literate southern European and eastern European origins.

Thus, in what should, on the face of it, have been a strongly pro-labor country, immigration restriction had to wait for an alignment of different interest groups with sufficient political muscle. Restrictionist policy became firmly entrenched when, with the concern over the resurgence of immigration from Europe in the post-WWI period, the national origins quota system was introduced in 1921 and reinforced in 1924. Immigration from the more highly skilled countries of the "older" immigrant sources (northwestern Europe) were favored, whereas immigration from the less developed and less skilled "newer" immigrant sources (southern and eastern Europe) was sharply curtailed.

\subsubsection{The Public Opinion Puzzle}

With the flourishing of democracy in the postwar period, policy should better reflect the balance of individual preferences. But here lies a puzzle: In democratic countries, public opinion in recent decades has been far more anti-immigrant than has public policy. A UN survey of government attitudes toward immigration records that 8 percent of developed country governments in 1976 considered immigration levels to be too high. This rose rapidly in the 1980s to reach 29 percent in 1995 (UN 1998, 71). But this still stands in sharp contrast with public opinion polls, which regularly find that two-thirds of the population would prefer less immigration. Studies of individual countries report that governments have consistently ignored widespread clamor for less immigration. This leads to two questions: What drives public opinion, and why is it not reflected in policy?

Recently a literature has emerged that analyzes public opinion polls to gain greater understanding of the motives lying behind anti-immigration sentiment. Economic self-interest is the most obvious motive, and this can be related either to the individual's own circumstances or to the tax implications of immigrant's use of public services. Second, some analysts argue that marginal groups are likely to identify with immigrants. Third, there is "contact theory," which essentially suggests that greater familiarity with immigrants reduces racism (although it could go the other way). A fourth fac- 
tor is ethnic-group politics. Members of individual ethnic or immigrant groups favoring the immigration of members of their own group formed political coalitions with other such groups to favor more general proimmigration policies.

One study for the United States in the 1980s found limited support for economic self-interest as reflected in being unemployed, being poor, suffering declining finances, or working as a manual laborer. But low-wage ethnic groups such as blacks and Hispanics were found to be less antiimmigration, and those living in high-immigrant-density areas more pro-immigration - a finding that supports marginality and contact motives (Fetzer 2000, 95-107). Similar analyses for France indicated that cultural threats were uppermost, whereas for Germany economic threats - for example, being poor or a manual laborer-were stronger. In both countries geographic concentrations of immigrants generated greater antiimmigration sentiment (Fetzer 2000, 131-39).

The most consistent results, from these and other studies, are that the more educated are always less anti-immigrant, and that attitudes toward immigrants vary with their legal status (e.g., legal or illegal) or ethnicity (country of origin). These findings are supported in an analysis of British social attitudes for 1983-90 by Dustmann and Preston (2001). They identify components of anti-immigrant sentiment arising from racism, concerns about cultural conflict, concerns about jobs, and concerns about the costs of welfare services. These in turn are related to the characteristics of individuals in the survey. They find prejudice against West Indian and Asian immigrants to be very strong, especially among the lowest education group. Concerns about immigrant welfare use are stronger among those higher up the income distribution. These results suggest a reason why the "classical" interest-group results are hard to observe in the data for overall attitudes to immigration where there is a redistributive welfare state. Those lower in the income distribution are less concerned about competition for jobs and welfare funds but are more racist, whereas those higher up are less racist but more concerned about the welfare burden. ${ }^{41}$

A recent study of the attitudes of Australian-born adults toward immigrants and ethnic minorities provides additional insight into these issues (Chiswick and Miller 1999). The analysis found that native-born Australians did not view the ethnic or racial background of immigrants as important if the immigrants were committed to Australia ( 89 percent), but they had negative reactions if "ethnic groups kept their own culture" (76 percent). They supported government subsidies for immigrants to learn English and to learn of government programs (94 percent), but many op-

41. For the United States, Scheve and Slaughter (2001) find a clear negative relationship between education or skill level and anti-immigrant sentiment. Differences between the United States and European countries may reflect the relative size of the welfare state. 
posed public money for ethnic groups to teach their origin language and culture to their children (47 percent). Negative attitudes toward immigration arise among those born in Australia from a view that multiculturalism is the basis of Australia's immigration policy ( 86 percent). The immigrants in the survey, on the other hand, had far more favorable attitudes toward their maintaining their own culture, toward public subsidies for this, and toward multiculturalism. The study also found that immigrants from nonEnglish-speaking countries who had more positive attitudes toward becoming Australian were more fluent and literate in English. Thus, Australians are more favorably disposed toward immigrants who want to be "Australians" culturally, and immigrants who are more favorably disposed toward becoming Australian have a more successful adjustment.

\subsubsection{Public Opinion and Public Policy}

One problem with such cross-sectional analyses is that they do not necessarily capture the forces that underlie changes in attitudes, which might be more relevant for public policy. Changes in real incomes, income distributions, the intensity of unemployment, racism, defense or strategic concerns, or media hype will not be reflected in static cross sections. Alternatively, it has been argued that the rise of an educated elite, beholden to, but not locked into, landed or capitalist interests has damped or even eliminated the impact of changes in opinion on policy. Thus, a recent study of postwar immigration policy in Great Britain concludes that "throughout the post-war period British policymakers were, taken as a whole, more liberal than the public to which they owed their office" (Hansen 2000, vi). Nevertheless, it is clear that governments have responded to rising or falling anti-immigrant public opinion but that the effects of public opinion have operated imperfectly, with a lag, and its influence in electoral politics has varied across time and place.

In Australia the proportion of adults saying that too many immigrants were being admitted rose from a mere 16 percent in 1961 to 68 percent in 1988. Betts (1988) argues that the lack of policy response in the face of such seismic changes in attitudes was due to the rise of the educated (and largely public-sector) elite. However, the steep increase in Australian antiimmigrant sentiment came between 1968 and 1972, and it was followed by sharp cuts in the immigration target by the incoming Whitlam government. Although immigration was not a central policy issue in the election campaign, it nevertheless played a key role at the margin in the Labour Party's election victory (Money 1999, 192).

Shifts in policy are not always reflected by changes in the ruling partyeither because other issues dominate or because policies toward immigration do not follow party lines. Thus, anti-immigration opinion increased in Great Britain during the 1960s, but it had little influence in the elections because most voters failed to see a difference between the political parties 
(Studlar 1978). Rather, both parties shifted their policies to a more antiimmigrant stance. In the 1970s the rise of strongly anti-immigrant minority parties shifted immigration controls up the agenda in majority party platforms. Thus, the presence of Jean Marie Le Pen's Front National influenced the debate in the French presidential election of 1974, and the rise of the National Front in Great Britain influenced Margaret Thatcher's stance on immigration in the parliamentary election of 1979.

Although immigration policies do respond to swings in public opinion, one might still argue (as Betts does for Australia) that they are not tight enough to reflect the widespread desire for less (often zero) immigration. This is in part because the bulk of immigrants to the developed world in the 1980s and 1990s were admitted through family reunification schemes or as refugees. To some degree this reflects humanitarian policies that are embodied in international treaties. But it also reflects the fact that reunification and refugee admissions command far more popular support than does primary immigration and, least of all, illegal immigration. Thus, seemingly tough policies toward some (illegals and spurious asylum-seekers) and generous policies toward others (reunification and refugees) largely reflect differences in popular opinion toward these different groups. At the same time, such policies often imply loss of administrative control over the total numbers admitted.

In the United States, attitudes toward immigration restriction cut across the conventional liberal (Democratic) and conservative (Republican) party lines. Pro-immigration policies are generally favored by conservative business and fruit-and-vegetable agricultural interests, as well as by liberal civil libertarians and members of recent immigrant and ethnic groups. Proimmigration policies are generally opposed by other conservative (nativist) groups, blue-collar workers, and union officials, as well as by some population control and environmentalist groups. With a declining trade union base in the private sector and an increasing share of its membership of recent immigrant origin, the leadership of the unions, particularly those involving low-skilled workers in internationally footloose industries, has been advocating a more pro-immigration position in the very tight labor market of the late 1990s. It remains to be seen whether the adoption of these new union attitudes will be reversed with a softening of the labor market.

The United States is seen as something of an exception in the late twentieth century, just as it was in the late nineteenth. Some observers see the proimmigration bias embodied in immigration reforms since the 1965 amendments as drawing its strength from the platforms of well-organized religious, ethnic, and civil rights groups (DeLaet 2000). A left-right coalition of these groups and employers' organizations provided support for the 1990 Immigration Act, which significantly raised the overall immigration quota despite opposition of the general public. Employer groups supported an increase in employment-based visas, whereas ethnic and civil rights 
groups supported an increase in family-based migrants (Lee 1998, 102-03). This coalition dominated the weaker and less united interest groups, including labor unions and conservative anti-immigrant groups, such as the Federation for American Immigration Reform (FAIR). Thus, just as one interest group coalition pushed the door closed in the early twentieth century, another propped it open wider in the late twentieth century.

\subsection{Conclusions: Migration and Policy}

\subsubsection{Migration and Globalization in the Long Run}

Immigration policy clearly has responded to globalizing forces since the age of mass migration began in the middle of the nineteenth century. At the end of the nineteenth century barriers were rising as labor became more abundant in the New World, real wage growth slowed, and income distributions widened. But the door was closed slowly and with a lag, as a result of nation building, unrepresentative politics, or interest group dynamics. Wars and the interwar depression intensified the process of restriction in the short term, a process that was reversed as stability returned in the early post-WWII period. In the early post-WWII years, narrowing income distributions and rapid wage growth provided permissive conditions for a return to a more open immigration policy in Europe and the New World. But from the 1970s, a rising demand for migration was accompanied by slower real wage growth and widening income distributions. Anti-immigration sentiment increased rapidly, and in some countries this was reflected in policy tightening aimed against labor migrants.

During the nineteenth and early twentieth centuries the colonial empires of the European powers furthered a dimension of globalization. Skilled workers (administrators, engineers, doctors, etc.), primarily from the colonial powers, were brought to the dependencies, but much larger numbers of unskilled workers from Asia, primarily from India and China, were brought to other less developed areas to work on the plantations and in the mines. This dimension of the globalization of labor markets had largely ended by World War I. Wars and the Depression interrupted the flow. The postWWII demise of these empires due to independence movements in Asia and Africa precluded its resuming.

The indirect effects of globalization have also been important. In the late nineteenth century, capital chased labor across the Atlantic to the resourceabundant New World. Although this raised the rental rates on land, the free flow of capital attenuated the diminishing returns to labor. In the absence of globalization in the capital market, it is likely that immigration controls would have come earlier. When the global capital market did implode in the interwar period, barriers rose more rapidly - even before the Great Depression. After the Second World War, as natural resource endowments be- 
came less important and as globalization returned to the capital market, the effects of migration on real wages and income distributions diminished. Globalizing capital markets, by attenuating the wage impacts of migration, helped to underpin liberalizing immigration policies up the mid-1970s and to dampen the immigration backlash in the following decades.

The integration of goods markets also influenced the shape of immigration policy. In the late nineteenth century declining transport costs eased relative factor scarcities and promoted wage convergence in the Atlantic economy. It was reflected in the invasion of New World agricultural goods into the Old World and of Old World manufactures into the New World. Although trade effects reduced the overall demand for labor in the Old World, they increased the relative demand for unskilled labor. And in the New World trade effects increased the relative demand for skilled labor. In the United States, at least, the McKinley and Dingley tariffs of 1890 and 1897, respectively, were aimed at protecting skilled labor by raising tariffs on a wide variety of manufactured and semimanufactured goods to protect American industry and labor from foreign competition. Had they not done so then perhaps barriers to immigration would have risen earlier, especially considering the protracted depression of the 1890s.

From the 1970s the globalization of trade lowered the returns to lowskilled labor in the first world and raised them in the labor-abundant third world. Trade hurt low-skilled workers in the first world relative to the skilled. Immigration simply added to the glut of low-skilled workers in the developed economies that was being created by trade and technical change. It is no surprise, then, that moves to restrict immigration since the early 1970s have been aimed principally at stemming the inflow of low-skilled workers - family unification policies notwithstanding.

\subsubsection{The Future of Immigration Policy}

The trend toward the integration and globalization of labor, product, and capital markets observed over the past few centuries is likely to continue. The decrease in the cost of information, communication, and transportation will encourage this development. The emergence of the poorer countries from the poverty trap will provide the resources to finance international migration, as will the emigrant remittances of kinsmen already in the high-income destinations. The continued pace of economic growth in the developed (OECD) countries will draw immigrants. The advanced economies will experience a high level of immigrant supply from the less developed countries in Latin America, Asia, and Africa. Yet these immigrants are entering technologically advanced economies in which there is a growing demand for high-skilled workers but shrinking relative employment opportunities for lower skilled workers. In this way the first decade of the twenty-first century differs from the first decade of the twentieth century. At that time there were still expanding opportunities for low-skilled workers in 
the industrial, mining, and agricultural sectors of the growing economies of overseas settlement.

Yet declining relative wages for low-skilled immigrant workers in the developed countries will still exceed the rising relative wages these workers are likely to receive in their less developed countries of origin. This will tend to bring about a greater convergence of wages by skill level across the globe. The wages of the high-skilled and the wages of the low-skilled will show less variance across international borders, but because of a steepening skill differential they will show perhaps even greater inequality in earnings within countries. This greater inequality and continued international migration is likely to be exacerbated by a substantially lower-than-replacement fertility rate in the economically advanced countries.

The current period differs from the earlier period in another dimension as well: There is now a much greater role for income distribution in the social welfare function. To a greater or lesser extent all of the developed economies have evolved into modern welfare states. This is evident from the much greater share of national income devoted to governmental income transfers to low-income groups in various forms - welfare payments, child allowances, unemployment compensation, health benefits, and old age assistance. This means that the widening of inequality (compared to what it would be otherwise as a result of low-skilled immigrants) plays a more prominent role in public policy. The result of increased low-skilled immigration and continued shrinking of job opportunities for low-skilled workers in the advanced economies as a result of the globalization of trade and technological change will mean increasing shares of national income transferred by the government to the low-skilled and poor native-born and immigrant populations.

The result will be a continuation of a process that we are already witnessing. Over the last few decades, the immigrant-receiving countries have been giving greater preference to high-skilled immigrants and have made the legal immigration of low-skilled workers that much more difficult. This has been done in the face of pressure for more "humanitarian visas" issued on the basis of a refugee status or a family relationship to someone already in the destination. Through the issuance of permanent visas or through temporary visas (e.g., the U.S. H1-B program), allocated on the basis of the worker's skill or occupation-specific employer petitions, high-skilled immigration can be expected to continue to grow.

A tightening of visa standards and numbers for kinship visas is also likely. The tightening of visa requirements for low-skilled workers will increase the supply of low-skilled illegal alien workers. Liberal democracies find it increasingly difficult to limit illegal immigration. Globalization is bringing about the reduction in barriers to mobility across countries. For example, the free movement of the citizens of the EU across member states makes it that much more difficult to limit the cross-border movement of im- 
migrant workers, whether legal or illegal, in their country of initial settlement. Free trade agreements even across countries with sharply different levels of economic development seem to bring forth arguments for less stringent restrictions on the mobility of people (e.g., the United States and Mexico in NAFTA). International tourism and family visits to relatives in developed economies expand with globalization, facilitating illegal employment after a legal entry. Border enforcement is of limited value when a liberal democracy shares a border with a less developed country, but the increase in illegal immigration in Japan suggests it is no longer possible, if it ever was, for even an island nation to seal its border from illegal entries (Weiner and Hanami 1998). Enforcement of immigration law in the interior of a liberal democracy, including the use of national identity cards and employer sanctions, comes into conflict with the growing appreciation for civil liberties and efforts to reduce regulatory burdens and the intrusiveness of the state.

The likely result will be a menu of policies. Public policy in the highincome countries will favor the migration of skilled workers of all sorts. Efforts to reduce family-based immigration will meet with only limited political success. Where they do not already exist, employer sanctions and national identity cards may be introduced to stem the tide of illegal aliens, but they will not be used effectively. Because draconian measures will not be used, the growing low-skilled illegal alien population will be beneficiaries of periodic amnesties. ${ }^{42}$ Until such time as there is substantial convergence in the incomes of workers of the same level of skill in the origin and destination countries (as was the case between Western Europe and North America), legal and illegal immigration pressures from the poorer to the wealthier nations will build up. Immigration restrictions may slow the numbers and shape the characteristics of the legal migrants, but the globalization and the integration of labor markets will continue well into the twenty-first century.

\section{References}

Abella, Manolo I. 1995. Asian migrant and contract workers in the Middle East. In The Cambridge survey of world migration, ed. Robin Cohen, 418-23. Cambridge: Cambridge University Press.

Altonji, Joseph G., and David Card. 1991. The effects of immigration on the labor

42. Shortly after this paragraph was first written, the Bush administration proposed an amnesty for several million illegal aliens from Mexico. Political pressures were exerted to expand it to all illegal aliens regardless of country of birth. The slowdown in the economy and reactions to the terrorist attacks in September 2001 by aliens, many of whom were in an illegal status, are likely to delay if not prevent this broad amnesty. 
market outcomes of less-skilled natives. In Immigration, trade, and the labor market, ed. J. M. Abowd and R. B. Freeman, 201-34. Chicago: University of Chicago Press.

Amjad, Rashid, ed. 1989. To the Gulf and back: Studies on the economic impact of Asian labour migration. New Delhi, India: ILO Asian Employment Programme.

Bartel, Ann P. 1989. Where do the new immigrants live? Journal of Labor Economics 7 (October): 371-91.

Bartel, Ann P., and Marianne J. Koch. 1991. Internal migration of U.S. immigrants. In Immigration, trade, and the labor market, ed. John M. Abowd and Richard B. Freeman, 121-34. Chicago: University of Chicago Press.

Bauer, Thomas, and Klaus F. Zimmerman. 1999. Assessment of possible migration pressure and its labour market impact following EU enlargement to Central and Eastern Europe. IZA Research Report no. 3. Bonn, Germany: IZA.

Betts, Katherine. 1988. Ideology and migration: Australia 1976 to 1987. Melbourne: Melbourne University Press.

Borjas, George J. 1994. The economics of immigration. Journal of Economic Literature 32 (4): 1667-717.

Borjas, George J., Richard B. Freeman, and Lawrence F. Katz. 1997. How much do immigration and trade affect labor market outcomes? Brookings Papers on Economic Activity, Issue no. 1:1-67.

Boyer, George R., Timothy J. Hatton, and Kevin H. O'Rourke. 1994. The impact of emigration on real wages in Ireland, 1850-1914. In Migration and the international labor market, 1850-1949, ed. Timothy J. Hatton and Jeffrey G. Williamson, 221-39. London: Routledge.

Butlin, Noel G. 1994. Forming a colonial economy: Australia 1810-1850. Cambridge: Cambridge University Press.

Card, David. 1990. The impact of the Mariel boatlift on the Miami labor market. Industrial and Labor Relations Review 43 (2): 245-57.

Card, David, and John Di Nardo. 2000. Do immigrant inflows lead to native outflows? American Economic Review 90:360-67.

Chiswick, Barry R. 1974. Income equality: Regional analyzes within a human capital framework. New York: National Bureau of Economic Research.

. 1980. An analysis of the economic progress and impact of immigrants. Washington, D.C.: U.S. Department of Labor, Employment and Training Administration, National Technical Information Service.

. 1982. The impact of immigration on the level and distribution of economic well-being. In The gateway: U.S. immigration issues and policies, ed. Barry R. Chiswick, 289-313. Washington, D.C.: American Enterprise Institute.

. 1988. Illegal immigration and immigration control. Journal of Economic Perspectives 3 (August): 101-15.

. 1993. Review of Immigration and the work force: Economic consequences for the United States and source areas, by George J. Borjas and Richard Freeman. Journal of Economic Literature 31 (June): 910-11.

1998. The economic consequences of immigration: Application to the United States and Japan. In Temporary workers or future citizens? Japanese and U.S. migration policies, ed. Myron Weiner and Tadashi Hanami, 177-208. New York: New York University Press.

2000. Are immigrants favorably self-selected? An economic analysis. In $\mathrm{Mi}$ gration theory: Talking across disciplines, ed. Caroline D. Brettell and James F. Hollifield, 61-76. New York: Routledge.

2001. The economics of illegal migration for the host economy. In International migration into the twenty-first century, ed. M. A. B. Siddique, 74-85. London: Edward Elgar. 
Chiswick, Barry R., and Paul W. Miller. 1999. Immigration, language, and multiculturalism in Australia. Australian Economic Review 32 (4): 369-85.

2001. Do enclaves matter for immigrant adjustment? University of Illinois at Chicago, Department of Economics. Photocopy.

Chiswick, Barry R., and Teresa A. Sullivan. 1995. The new immigrants. In State of the union: America in the 1990s. Vol. 2, Social trends, ed. R. Farley, 211-70. New York: Russell Sage.

Chiswick, Carmel U., Barry R. Chiswick, and Georgios Karras. 1992. The impact of immigrants on the macroeconomy. Carnegie-Rochester Conference Series on Public Policy 37 (4): 279-316.

Cobb-Clark, Deborah A., and Marie D. Connolly. 1997. The worldwide market for skilled migrants: Can Australia compete? International Migration Review 31 (3): 670-93.

Collins, William, Kevin H. O’Rourke, and Jeffrey G. Williamson. 1999. Were trade and factor mobility substitutes in history? In Migration: The controversies and the evidence, ed. Riccardo Faini, Jaime De Melo, and Klaus Zimmermann, 227-60. Cambridge: Cambridge University Press.

Daniels, Roger. 1995. The growth of restrictive immigration policy in the colonies of settlement. In The Cambridge survey of world migration, ed. Robin Cohen, 39-46. Cambridge: Cambridge University Press.

Daniels, Roger, and Otis L. Graham. 2001. Debating American immigration: 1882 present. Lanham, Md.: Rowman and Littlefield.

DeLaet, Debra L. 2000. U.S. immigration policy in an age of rights. Westport, Conn.: Praeger.

Dunlevy, James A. 1978. Economic opportunity and the responses of new and old immigrants in the United States. Journal of Economic History 38 (4): 901-17.

Dunlevy, James A., and R. P. Saba. 1992. The role of nationality-specific characteristics on the settlement patterns of late-nineteenth century European immigrants. Explorations in Economic History 29 (2): 228-49.

Dustmann, Christian, and Ian Preston. 2001. Racial and economic factors in attitudes toward immigration. University College, London, Department of Economics. Photocopy.

Easterlin, Richard. 1961. Influences in European overseas emigration before World War I. Economic Development and Cultural Change 9 (April): 33-51.

Eltis, David. 1983. Free and coerced transatlantic migrations: Some comparisons. American Historical Review 88 (2): 251-80.

Engerman, Stanley L. 1986. Servants to slaves to servants: Contract labor and European expansion. In Colonialism and migration: Indentured labor before and after slavery, ed. E. van den Boogaart and P. C. Emmer, 263-94. Dordrecht, The Netherlands: Martinus Nijhof.

Erickson, Charlotte. 1994. Leaving England: Essays on British emigration in the nineteenth century. Ithaca, N.Y.: Cornell University Press.

Faini, Riccardo, and Alessandra Venturini. 1994. Italian emigration in the pre-war period. In Migration and the international labor market, 1850-1939, ed. Timothy J. Hatton and Jeffrey G. Williamson, 72-90. London: Routledge.

Ferenczi, Imre, and Walter F. Willcox. 1929. International migrations. Vol. 1. New York: National Bureau of Economic Research.

Ferrie, Joseph P., and Joel Mokyr. 1994. Immigration and entrepreneurship in the nineteenth century U.S. In Economic aspects of international migration, ed. Herbert Geirsch, 115-38. Berlin: Springer-Verlag.

Fetzer, Joel S. 2000. Public attitudes toward immigration in the United States, France, and Germany. Cambridge: Cambridge University Press. 
Filer, Randall K. 1992. The effect of immigrant arrivals on migratory patterns of native workers. In Immigration and the workforce: Economic consequences for the United States and source areas, ed. George J. Borjas and Richard B. Freeman, 245-70. Chicago: University of Chicago Press.

Foreman-Peck, James. 1992. A political economy of international migration, 18151914. Manchester School of Economics and Social Studies 60 (4): 359-76.

Friedberg, Rachel M. 2001. The impact of mass migration on the Israeli labor market. Quarterly Journal of Economics 105 (1): 1373-408.

Galenson, David W. 1981. White servitude in Colonial America. Cambridge: Cambridge University Press.

Gemery, Henry A. 1994. Immigrants and emigrants: International migration and the U.S. labor market in the Great Depression. In Migration and the international labor market, 1850-1939, ed. Timothy J. Hatton and Jeffrey G. Williamson. London: Routledge.

Goldin, Claudia. 1994. The political economy of immigration restriction in the United States. In The regulated economy: A historical approach to political economy, ed. Claudia Goldin and G. D. Libecap, 223-58. Chicago: University of Chicago Press.

Gould, John D. 1979. European intercontinental emigration, 1815-1914: Patterns and causes. Journal of European Economic History 8 (3): 593-679.

Green, Alan G., and David A. Green. 1993. Balanced growth and the geographical distribution of European immigrant arrivals to Canada, 1900-12. Explorations in Economic History 30 (1): 31-59.

Greenwood, Michael J., and John M. McDowell. 1994. The national labor market consequences of U.S. immigration. In Economic aspects of international migration, ed. Herbert Giersch, 155-94. Berlin: Springer-Verlag.

Grubb, Farley. 1992. The long-run trend in the value of European immigrant servants: New measurements and interpretations. Research in Economic History 14:167-241.

Hansen, Randall. 2000. Citizenship and immigration in postwar Britain. Oxford: Oxford University Press.

Hatton, Timothy J. 1995. A model of U.K. emigration, 1870-1913. Review of Economics and Statistics 77 (3): 407-15.

- 2001. Why has U.K. net emigration increased? University of Essex, Department of Economics. Unpublished manuscript.

Hatton, Timothy J., and Jeffrey G. Williamson. 1998. The age of mass migration: Causes and economic effects. New York: Oxford University Press.

2001. Demographic and economic pressure on emigration out of Africa. NBER Working Paper no. 8124. Cambridge, Mass.: National Bureau of Economic Research.

Herbert, Ulrich, and Karin Hunn. 2000. Guest workers and policy on guest workers in the Federal Republic: From the beginning of recruitment in 1955 until its halt in 1973. In The miracle years: A cultural history of West Germany, ed. Hanna Schissler, 180-208. Princeton, N.J.: Princeton University Press.

Hu-De Hart, Evelyn. 1995. The Chinese of Peru, Cuba, and Mexico. In The Cambridge survey of world migration, ed. Robin Cohen, 220-22. Cambridge: Cambridge University Press.

Hui, Ong Jin. 1995. Chinese indentured labor: Coolies and colonies. In The Cambridge survey of world migration, ed. Robin Cohen, 51-57. Cambridge: Cambridge University Press.

Jasso, Guillermina, Mark R. Rosenzweig, and Mark R. Smith. 2000. The changing skill of new immigrants to the United States: Recent trends and their determi- 
nants. In Issues in the economics of immigration, ed. George J. Borjas, 185-226. Chicago: National Bureau of Economic Research.

Jerome, Harry. 1926. Migration and business cycles. New York: National Bureau of Economic Research.

Kamemera, David, Victor I. Oguledo, and Bobby Davis. 2000. A gravity model analysis of international migration to North America. Applied Economics 32 (13): 1745-55.

Karras, Georgios, and Carmel U. Chiswick. 1999. Macroeconomic determinants of migration: The case of Germany, 1964-1988. International Migration 37 (4): 657 77.

Keeling, Drew. 1999. The transport revolution and transatlantic migration, 1850 1914. Research in Economic History 19:39-74.

Kirk, Dudley. 1946. Europe's population in the interwar years. Geneva: League of Nations.

Lee, Kenneth K. 1998. Huddled masses, muddled laws: Why contemporary immigration policy fails to reflect public opinion. Westport, Conn.: Praeger.

Leff, Nathaniel H. 1982. Underdevelopment and development in Brazil. Vol. 1, Economic structure and change, 1822-1947. London: George Allen and Unwin.

Lovejoy, Paul E. 1983. The volume of the Atlantic slave trade: A synthesis. Journal of African History 23 (4): 473-501.

Lowell, Bryant L. 1987. Scandinavian exodus: Demography and social development of nineteenth-century rural communities. Boulder, Colo.: Westview.

Madgwick, R. B. 1937. Immigration into eastern Australia, 1788-1851. London: Longmans Green.

McDonald, J., and Ralph Shlomowitz. 1990. Mortality on immigrant voyages to Australia. Explorations in Economic History 27 (1): 84-113.

- 1991. Passenger fares on sailing vessels to Australia in the nineteenth century. Explorations in Economic History 28 (2): 192-208.

Money, Jeannette. 1999. Fences and neighbors: The political geography of immigration control. Ithaca, N.Y.: Cornell University Press.

Organization for Economic Cooperation and Development (OECD). 2000. Combating the illegal employment of foreign workers. Paris: OECD.

O'Rourke, Kevin H., and Jeffrey G. Williamson. 1997. Around the European periphery 1870-1913: Globalization, schooling, and growth. European Review of Economic History 1 (2): 153-90.

O’Rourke, Kevin H., Jeffrey G. Williamson, and Timothy J. Hatton. 1994. Mass migration, commodity market integration, and real wage convergence: The late nineteenth century Atlantic economy. In Migration and the international labor market, 1850-1939, ed. T. J. Hatton and J. G. Williamson, 203-20. London: Routledge.

Rotte, Ralph, Michael M. Vogler, and Klaus F. Zimmermann. 1997. South-north refugee migration: Lessons for development co-operation. Review of Development Economics 1 (1): 99-115.

Scheve, Kenneth F., and Matthew J. Slaughter. 2001. Labor market competition and individual preferences over immigration policy. Review of Economics and Statistics 83:133-45.

Shaw, Alan G. L. 1966. Convicts and the colonies. Melbourne: Melbourne University Press.

Shimpo, Mitsuru. 1995. Indentured migrants from Japan. In The Cambridge survey of world migration, ed. Robin Cohen, 48-50. Cambridge: Cambridge University Press. 
Shughart, William F., Robert D. Tollinson, and Mwangi S. Kimenyi. 1986. The political economy of immigration restrictions. Yale Journal on Regulation 4 (1): 7997.

Stalker, Peter. 1994. The work of strangers: A survey of international labor migration. Geneva: International Labor Organization.

Studlar, Dudley T. 1978. Policy voting in Britain: The colored immigration issue in the 1964, 1966, and 1970 general elections. American Political Science Review 72 (1): 46-64.

Tatla, Darshan Singh. 1995. Sikh free and military migration during the colonial period. In The Cambridge survey of world migration, ed. Robin Cohen, 69-73. Cambridge: Cambridge University Press.

Taylor, Alan M., and Jeffrey G. Williamson. 1997. Convergence in the age of mass migration. European Review of Economic History 1 (1): 27-63.

Thiara, Ravinder K. 1995. Indian indentured workers in Mauritius, Natal, and Fiji. In The Cambridge survey of world migration, ed. Robin Cohen, 63-68. Cambridge: Cambridge University Press.

Timmer, Ashley S., and Jeffrey G. Williamson. 1998. Immigration policy prior to the 1930s: Labor markets, policy interactions, and globalization backlash. Population and Development Review 24 (4): 739-71.

Todaro, Michael P. 1969. A model of labor migration and urban unemployment in less developed countries. American Economic Review 59 (1): 138-48.

Twaddle, Michael. 1995. The settlement of South Asians in East Africa. In The Cambridge survey of world migration, ed. Robin Cohen, 74-76. Cambridge: Cambridge University Press.

United Nations (UN). 1979. Trends and characteristics of international migration since 1950. New York: UN.

1998. World population monitoring 1997: International migration and development. New York: UN. UN.

1999. World population prospects: The 1998 revision. Washington, D.C.:

2000. World migration report. New York: UN International Organization for Migration.

U.S. Immigration and Naturalization Service. 2000. Statistical yearbook of the Immigration and Naturalization Service, 1998. Washington, D.C.: GPO.

Vertovec, Steven. 1995. Indian indentured migration to the Caribbean. In The Cambridge survey of world migration, ed. Robin Cohen, 57-62. Cambridge: Cambridge University Press.

Weiner, Myron, and Tadashi Hanami, eds. 1998. Temporary workers or future citizens? Japanese and U.S. migration policies. New York: New York University Press.

Williamson, Jeffrey G. 1998. Globalization, labor markets, and policy backlash in the past. Journal of Economic Perspectives 12 (4): 51-72.

Williamson, Jeffrey G., and Peter H. Lindert. 1980. American inequality: A macroeconomic history. New York: Academic Press.

Winklemann, Rainer. 2000. Immigration policies and their impact: The case of New Zealand and Australia. IZA Discussion Paper no. 169. Bonn, Germany: IZA-Institute for the Study of Labor.

Wooden, Mark, Robert Holton, Graeme Hugo, and Judith Sloan. 1994. Australian immigration: A survey of the issues. Canberra, Australia: Australian Government Printing Service.

Yang, Philip Q. 1995. Post-1965 immigration to the United States: Structural determinants. Westport, Conn.: Praeger. 


\section{Comment Riccardo Faini}

Migration is a controversial and divisive issue. By taking a broad historical perspective, Barry R. Chiswick and Timothy J. Hatton are able to cast new light on an old debate. Their paper covers a lot of ground. It provides the reader with a fascinating overview of the main trends in international migration starting back in the seventeenth century; it offers an in-depth discussion of the determinants of mass migration; it then takes a close look at the impact of migration; and finally it assesses the role of political economy factors in shaping policies toward migration.

The main messages of the paper can be summarized as follows. First, migration is quite responsive to basic economic incentives. This is best seen in the nineteenth century, before immigration policies took a restrictive turn, thereby muting the impact of wage and employment conditions. Second, the labor market impact of migration comes mainly through its effects on economywide factor endowments. Third, given the growing emphasis in host countries on income distribution considerations, the restrictive stance toward unskilled migration is likely to continue.

The first point is well taken, although the explanatory power of wage and employment conditions should not be overestimated (as the authors themselves acknowledge when they emphasize other factors, such as financial constraints, demography, and chain effects). It is true, for instance, that the migration transition in southern Europe during the second half of the twentieth century owes much to the catching-up process with respect to the rest of the continent. However, although there was some wage convergence, it was at best incomplete. Moreover, while wage converged, unemployment diverged. Given that, as shown by Hatton (1995), migration should respond more to unemployment differentials than to wage differentials, we would have expected emigration from southern Europe to rise rather than falling. To understand why it did not we need to look at additional factors, such as the levels of unemployment and income (rather than simply their differentials). High unemployment rates in receiving countries may well discourage migration, even if unemployment differentials are unchanged. Similarly, if income rises at home, potential migrants may be increasingly unwilling to suffer the emotional and cultural shocks associated with migration, even if the wage differential with the host country remains unchanged. Finally, additional factors emphasized in the so-called new migration literature may also have a role to play. For instance, there is some evidence that the desire for risk diversification has been a significant motive for emigration from backward economies, where insurance markets are relatively underdevel-

Riccardo Faini is professor of economics at the University of Brescia. Currently, he is on leave at the Ministry of Economy in Italy. 
oped. There are good a priori reasons to believe that it may have played a similar role in affecting intercontinental migration flows in the nineteenth century.

The second point, namely that the economic impact of migration works through its effects on relative factor endowments, is also well taken. Under the reasonable assumption that migrants have less overall capital than natives, income will fall, in a static model, and growth will slow down, at least temporarily, in a dynamic model. However, we should not overlook one basic fact, namely that the welfare impact of immigration is not the same as its growth and income effect. This is better seen in a static Barry-Soligo model, where gross domestic product (GDP) per capita definitely falls after immigration of capital poor workers, but natives' welfare unambiguously increases. The fall in GDP is explained by the fact that immigrants are relatively poor (they have little or no capital) and therefore drive down average income in the host country. Natives gain, however, because the fall in wages is more than offset by higher returns to capital. Further immigration is even more beneficial to natives, since it drives down the wage of previous migrants. Borjas (1995) has also noticed that the welfare impact of immigration is a decreasing function of the wage elasticity of labor demand. If wages do not fall — say, because labor demand is infinitely elastic - the welfare impact is nil. There is a trade-off, therefore, between the welfare and the distributional impact: For the former to be large, we also need the latter to be large.

The third part of the paper deals with the political economy of immigration. The authors highlight one puzzle, which is that "in democratic countries public opinion in recent years has been far more anti-immigration than public policy." This may be true, but the fact is that by and large immigration policies have become significantly more restrictive in the twentieth century, after the First World War, than in the previous period. Interestingly enough, this shift is mirrored by an opposite shift in the policy stance toward trade that used to be quite restrictive in the nineteenth century and was significantly liberalized after the Second World War. There is therefore an additional and equally surprising puzzle, namely the substantial asymmetries in the policy stance on goods trade and migration. In the traditional trade model, these aspects - and one could add capital flows as well-are all substitutes. Limiting one flow is ineffective if the other flow is unrestricted. Are voters in democratic countries therefore so myopic that they do not realize that restrictions on immigration are negated by the liberal stance on trade policies and capital flows? The typical answer of the profession is that the relationships among migration, capital mobility, and trade are complex and model dependent. However, we can be somewhat more exhaustive and note some factors that may plausibly explain why the stance toward migration is more restrictive than that on trade. First, migration is likely to be significantly less reversible than goods trade. Whereas factor 
services embodied in imports can be easily stopped through temporary protection measures, expelling migrants on purely economic reasons is unacceptable to most. Second, immigrants may compete with natives in the nontraded-goods sector in a way that imports do not. In both cases, we would still be left with the task of explaining why in the nineteenth century migration policy was more liberal than trade policy. Clearly, this is an area with substantial scope for additional research.

To conclude, Chiswick and Hatton highlight two major differences between the first and the most recent globalization episodes, namely the much diminished demand for unskilled workers and the more significant role for income distribution considerations in receiving countries. There is, however, a third major difference, which has to do with the impact of migration flows in sending countries. Although this latter aspect is somewhat neglected by the authors, they can hardly be blamed for such an omission, given that even the Handbook of Population Economics says very little on this issue. However, the truth is that although migration flows played a key role in fostering convergence between the Old and the New worlds until 1913, this is no longer the case in the current globalization phase. The fact that immigration policy is increasingly geared to limit unskilled immigration and favor skilled immigration has indeed far-reaching implications for sending countries. First, unskilled labor flows are no longer there to foster convergence as they did quite successfully in the nineteenth century and in the 1960s in Europe. Second, immigration policy in receiving countries will aggravate the brain drain and its related negative effects on the sending country. There is also some evidence (Faini 2002) that skilled migrants have a lower propensity to remit home, most likely because they tend to migrate permanently and bring along their family. Overall, sending countries therefore lose on all three counts, the more limited role of unskilled migration, the decline in human capital attendant on skilled emigration, and the dearth of remittances flows. There is still a long way to go to the globalization of labor markets.

\section{References}

Borjas, George. 1995. The economic benefits from immigration. Journal of Economic Perspectives (Spring): 3-22.

Faini, Riccardo. 2002. Development, trade, and migration. Revue d'Economie et $d u$ développement (forthcoming).

Hatton, Timothy. 1995. A model of U.K. emigration, 1875-1913. Review of Economics and Statistics 77 (3): 407-15. 